Kelly Yoshizaki

\title{
Efeito subcrônico do diesel no epitélio nasal e na via aérea em modelo murino
}

Dissertação apresentada à Faculdade de Medicina da Universidade de São Paulo para a obtenção do título de Mestre em Ciências

Área de concentração: Fisiopatologia Experimental

Orientadora: Dra. Mariangela Macchione 
Dados Internacionais de Catalogação na Publicação (CIP)

Preparada pela Biblioteca da

Faculdade de Medicina da Universidade de São Paulo

\section{Creprodução autorizada pelo autor}

Yoshizaki, Kelly

Efeito subcrônico do diesel no epitélio nasal e na via aérea em modelo murino /

Kelly Yoshizaki. -- São Paulo, 2009.

Dissertação(mestrado)--Faculdade de Medicina da Universidade de São Paulo para obtenção do título de Mestre em Ciências.

Área de concentração: Fisiopatologia Experimental.

Orientadora: Mariangela Macchione.

Descritores: 1.Poluição do ar 2.Material particulado 3.Epitélio nasal 4.Nariz 5.Pulmão 6.Interleucinas 7.Mucina-5AC 8.Hiperplasia 9.Camundongos

USP/FM/SBD-437/09 
Dedico este trabalho a minha querida familia por todo o apoío em todas as etapas da minha vida. 


\section{AGRADECIMENTOS}

$\mathcal{A}$ minha orientadora, Dra Mariangela Macchione, por todo o ensino, apoio e amizade durante estes anos. Agradeço a confíança que me foi dada para a condução dos trabalhos.

Ao Prof Paulo Hílário Saldiva pelo ensino, suporte e discussão do trabalho.

$\dot{\mathcal{A}}$ Dra. Thais Mauad, pela atenção e ajuda em diversas ocasióes na análíse das lâminas e do trabalho.

Ao Dr. Luis Fernando Ferraz Sílva, pela ajuda na análise de imagem.

ג̇ Dra. NNaomi Kondo, pelas importantes sugestões na análise dos resultados.

À Profa Elía, Tânía e Sônía do Programa de Fisiopatología Experimental.

A Sandra e a todos do Caboratório de Imunohistoquimica do Departamento de Patología, pelo apoio na títulação e confecção das lâminas.

$\mathcal{A}$ Kelly e todas queridas técnicas do laboratório de Histologia do Departamento de Patologia, pelo apoio na confecção das lâminas.

As amigas que apoiaram este trabalho Mara, Alessandra, Vivien, Laísa Moreira, Ana Laura. $\mathcal{E}$ Regiane, Lícia, Márcia, Andréia, Daniela, Robson e todos os colegas do Grupo de Defesa Pulmonar, pela amizade e acolhida durante o periodo de trabalho.

Aos colegas dos Laboratórios de Poluição Atmosférica Experimental pela troca de informações nos momentos necessários, auxiliando de forma direta ou indireta a realização deste trabalho. 
Aos colegas do Biotério pelo cuidado com os animais durante o período de exposição deste estudo.

A Coordenação de Aperfeiçoamento de Pessoal de $\mathcal{N} i v e l$ Superior-CAPES, pelo apoí financeiro para a realização deste trabalho.

Wellington $\mathcal{H}$ Tizuka, pelas constantes demonstrações de carinho e bem-querer, que são também, incentivo e estimulo. 


\section{SUMÁRIO}

\section{Lista de abreviaturas}

Lista de símbolos

Lista de tabelas

Lista de gráficos

Lista de figuras

\section{RESUMO}

\section{SUMMARY}

INTRODUÇÃO.

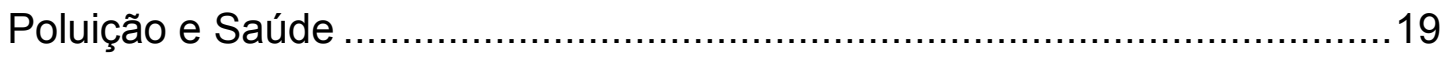

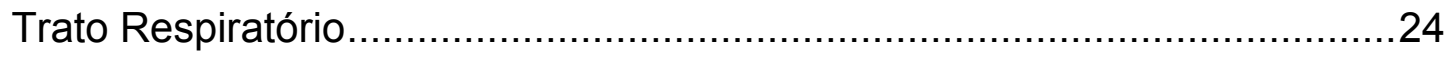

Vias Aéreas Superiores (Trato Respiratório Proximal) e Epitélio Nasal ........25

Vias Aéreas Inferiores (Trato Respiratório Distal) ................................27

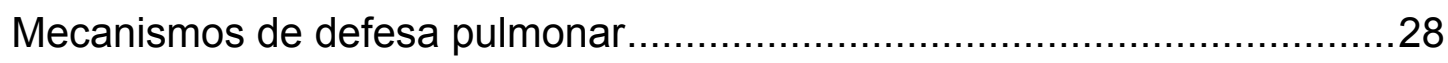

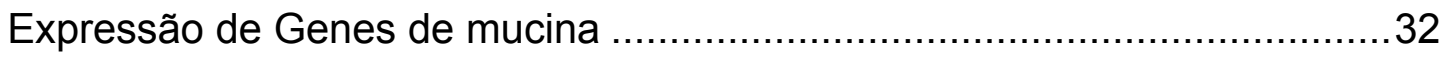

Componentes da resposta inflamatória e mediadores químicos ..................35

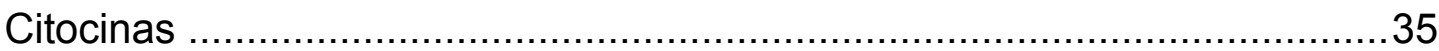

Relevância dos parâmetros biológicos em estudos de

poluição 39

OBJETIVOS

MATERIAIS E MÉTODOS

Animais

Coleta do material particulado do diesel 
Grupos experimentais e Administraçao da soluçao teste

Obtençao das células inflamatorias: coleta e analise do lavado

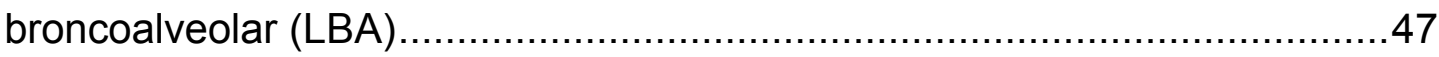

Quantificaçao demediadores inflamatorios ........................................47

Determinação da espessura do epitelio nasal e brônquico .........................49

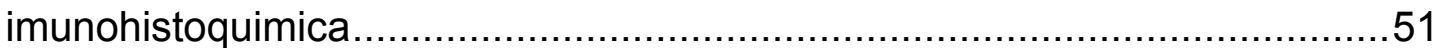

Quantificaçao da expressão de mediadores inflamatórios no tecido epitelial.53

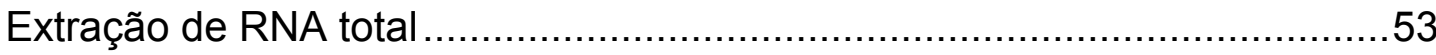

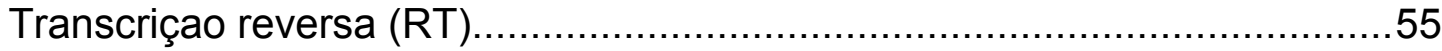

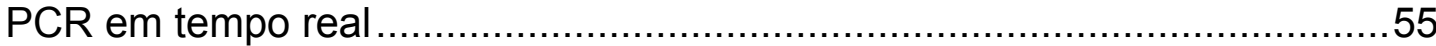

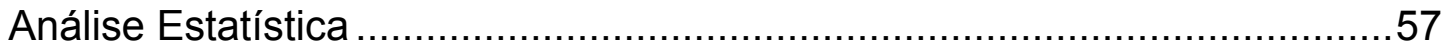

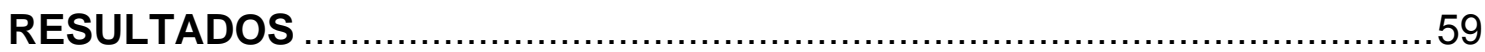

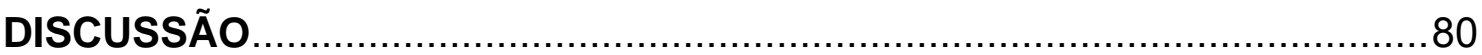

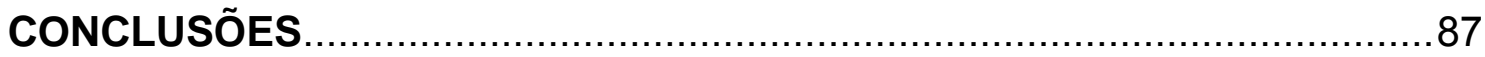

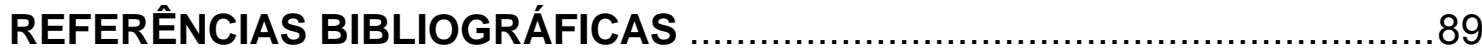

ANEXOS 


\section{LISTA DE ABREVIATURAS}

$\begin{array}{ll}\text { PBS } & \text { Solução salina tamponada com fosfato } \\ \text { LBA } & \text { Lavado broncoalveolar } \\ \text { DEP } & \text { Partícula de combustão do diesel } \\ \text { IL } & \text { Interleucina } \\ \text { CETESB } & \text { Companhia de Tecnologia de Saneamento Ambiental } \\ \text { EPA } & \text { Agencia Americana de Proteção Ambiental } \\ \text { HE } & \text { Hematoxilina-Eosina } \\ \text { IL-13 } & \text { Interleucina 13 } \\ \text { IL-4 } & \text { Interleucina 4 } \\ \text { IL-10 } & \text { Interleucina 10 } \\ \text { IL-17 } & \text { Interleucina 17 } \\ \text { MUC5ac } & \text { Mucina 5ac } \\ \text { MP } & \text { Material particulado do diesel } \\ \text { PAS/AB } & \text { Ácido Periódico de Schiff e Azul Alciano }\end{array}$




\section{LISTA DE SÍMBOLOS}

$\begin{array}{ll}\mu g & \text { Micrograma } \\ \mu \mathrm{g} / \mu \mathrm{L} & \text { Micrograma/microlitro } \\ \mu \mathrm{m} & \text { Micrômetros } \\ \mathrm{mg} & \text { Miligramas } \\ \mathrm{pH} & \text { Concentração de íons hidrogênio } \\ \mathrm{PM} 10 & \quad \text { Particulas com diâmetro aerodinâmico inferior a } 10 \mu \mathrm{m} \\ \mathrm{PM} 2,5 & \text { Particulas com diâmetro aerodinâmico inferior a 2,5 } \mu \mathrm{m} \\ \mathrm{ppm} & \text { Partes por milhão } \\ \mathrm{rpm} & \text { Respirações por minuto } \\ \text { ng/g } & \text { Nanogramas por gramas } \\ \text { t/ano } & \text { Toneladas por ano }\end{array}$




\section{LISTA DE TABELAS}

Tabela 1. Relação de algumas interleucinas relacionadas à origem e participação na inflamação 38

Tabela 2. Conteúdo de Metais (ppm) e Hidrocarbonetos Policíclicos Aromáticos (ng/g) de Partículas de Diesel.............................................44

Tabela 3. Oligonucleotídeos usados no ensaio de PCR em tempo real.....56 


\section{LISTA DE GRÁFICOS}

Gráfico 1. Representação gráfica dos efeitos do DEP sobre a espessura da camada epitelial das vias aéreas proximais (septo nasal)

Gráfico 2. Efeito do DEP de concentrações $15 \mu \mathrm{g} / 10 \mu \mathrm{l}$ e $30 \mu \mathrm{g} / 10 \mu \mathrm{l}$ de salina e grupo Controle sobre a porcentagem de área epitelial ocupada por muco ácido no septo nasal 62

Gráfico 3. Efeito do DEP de concentrações $15 \mu \mathrm{g} / 10 \mu \mathrm{l}$ e $30 \mu \mathrm{g} / 10 \mu \mathrm{l}$ de salina e grupo Controle sobre a porcentagem de área epitelial ocupada por muco neutro no septo nasal. 63

Gráfico 4. Efeito do DEP nas concentrações $15 \mu \mathrm{g} / 10 \mu \mathrm{l}$ de solução salina e $30 \mu g / 10 \mu l$ de solução salina e o grupo Controle sobre o número total de células inflamatórias no lavado broncoalveolar (LBA). 64

Gráfico 5. Representação gráfica do efeito do DEP nas concentrações $15 \mu \mathrm{g} / 10 \mu \mathrm{l}$ e $30 \mu \mathrm{g} / 10 \mu \mathrm{l}$ de salina e grupo Controle sobre o número de macrófagos encontrados no lavado broncoalveolar (LBA) nos períodos de 30 e 60 dias. .65

Gráfico 6. Efeito do DEP nas concentrações $15 \mu \mathrm{g} / 10 \mu \mathrm{l}$ e $30 \mu \mathrm{g} / 10 \mu \mathrm{l}$ de solução salina e grupo Controle sobre o número de linfócitos no lavado broncoalveolar (LBA). 66

Gráfico 7. Efeito do DEP nas concentrações $15 \mu \mathrm{g} / 10 \mu \mathrm{l}$ e $30 \mu \mathrm{g} / 10 \mu \mathrm{l}$ de salina e grupo Controle sobre o número de neutrófilos no lavado broncoalveolar (LBA). 67 
Gráfico 8. Efeito do DEP nas concentrações $15 \mu \mathrm{g} / 10 \mu \mathrm{l}$ e $30 \mu \mathrm{g} / 10 \mu \mathrm{l}$ de salina e grupo controle sobre o número de eosinófilos no lavado broncoalveolar (LBA). .68

Gráfico 9. Efeito do DEP de concentrações $15 \mu \mathrm{g} / 10 \mu \mathrm{l}$ e $30 \mu \mathrm{g} / 10 \mu \mathrm{l}$ de salina e grupo controle sobre células inflamatórias positivas para IL- 13 . 69 Gráfico 10. Efeito do DEP de concentrações $15 \mu \mathrm{g} / 10 \mu \mathrm{l}$ e $30 \mu \mathrm{g} / 10 \mu \mathrm{l}$ de salina e grupo Controle sobre células inflamatórias positivas para IL- 4 .......70 Gráfico 11. Efeito do DEP de concentrações $15 \mu \mathrm{g} / 10 \mu \mathrm{l}$ e $30 \mu \mathrm{g} / 10 \mu \mathrm{l}$ de salina e grupo Controle sobre células inflamatórias positivas para IL- 10.....71 Gráfico 12. Efeitos do DEP sobre a espessura da camada epitelial do trato respiratório distal .73

Gráfico 13. Efeito do DEP de concentrações de DEP $15 \mu \mathrm{g} / 10 \mu \mathrm{l}$ e $30 \mu \mathrm{g} / 10 \mu \mathrm{l}$ de salina e grupo Controle sobre a expressão reativa do gene de MUC5ac de tecido pulmonar. .74

Gráfico 14. Efeitos do DEP nas concentrações de concentrações $15 \mu \mathrm{g} / 10 \mu \mathrm{l}$ e $30 \mu g / 10 \mu l$ de salina e grupo Controle sobre a expressão de inflamação peribrônquica positiva para IL-13 (área+/área). .76

Gráfico 15. Efeitos do DEP nas concentrações de concentrações $15 \mu \mathrm{g} / 10 \mu \mathrm{l}$ e $30 \mu g / 10 \mu l$ de salina e grupo Controle sobre a expressão de inflamação peribrônquica positiva para IL-13 (área+/menbrana basal) 77 


\section{LISTA DE FIGURAS}

Figura 1. Tamanho e composição do material particulado da poluição do ar ..21

Figura 2. Emissões relativas de poluentes por tipo de fonte

Figura 3. Resposta das células secretoras das vias aéreas para eventos agudos ou crônicos

Figura 4. Regulação temporal e espacial da expressão do gene de mucina ...38

Figura 5. Representação da interleucina-13.

Figura 6. Fluxograma representando o período de instilação intranasal de DEP de concentrações $15 \mu \mathrm{g}, 30 \mu \mathrm{g}$ (diluído em $10 \mu$ de solução salina) e solução salina (grupo Controle) nos animais.

Figura 7. Ilustração da superfície ventral do crânio de camundongo evidenciando a estrutura utilizada para marcar o "ponto de corte" da cavidade nasal. 49

Figura 8. O epitélio respiratório que reveste o septo da cavidade nasal.....60

Figura 9. Representação histológica do epitélio brônquico .72

Figura 10. Representação histológica da expressão de IL-13 do epitélio brônquico. .75

Figura 11. Partículas de Diesel fagocitadas pelo macrófago no pulmão após 60 dias no grupo que recebeu DEP30. .78 


\section{RESUMO}

Yoshizaki K. Efeito subcrônico do diesel no epitélio nasal e da via aérea em modelo murino. [Dissertação]. São Paulo: Faculdade de Medicina, Universidade de São Paulo; 2009.

A combustão do diesel (DEP) é a principal fonte de partículas ultrafinas (PUFs)-relacionadas à poluição causada pelo tráfego. Indivíduos com doenças respiratórias crônicas estão propensos a exacerbações durante a exposição à poluição ambiente. Este estudo avaliou os efeitos de exposição subcrônica a uma baixa dose de partículas de combustão de diesel (DEP). 90 camundongos machos BALB/c foram divididos em 3 grupos: (a) Controle: instilação nasal de solução salina $(n=30)$; (b) DEP15: $15 \mu \mathrm{g}$ de DEP/10 $\mu$ de

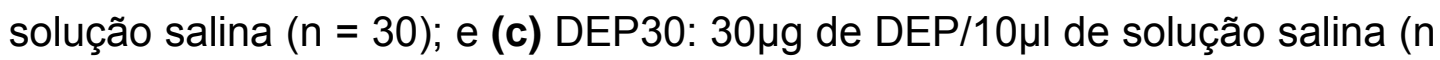
= 30) durante cinco dias por semana, por 30 e 60 dias. Os animais foram anestesiados com pentobarbital de sódio $(50 \mathrm{mg} / \mathrm{kg}$ ip) e sacrificados por exanguinação. A contagem de células inflamatórias e as concentrações de interleucinas (IL) -4, -10, -13 e -17 no lavado broncoalveolar (LBA) foram avaliadas por ensaio imunoenzimático (Elisa). mRNA da MUC5ac foi avaliado por PCR em tempo real. A análise histológica do septo nasal e bronquíolos foi realizada para avaliar: (a) a espessura do epitélio brônquico e nasal, (b) o conteúdo de muco neutro e ácido na mucosa nasal. Nossos resultados mostraram que a instilação de DEP30 após 30 dias aumentou o número de células inflamatórias totais em relação ao controle $(p=0,033)$. Ao comparar os resultados de DEP30 com o grupo Controle após 60 dias 
observamos os seguintes aumentos: (a) na expressão de MUC5AC nos pulmões ( $p=0,016)$, no conteúdo de muco ácido no septo nasal ( $p=0,017)$, nas células inflamatórias totais no LBA $(p<0,001)$, no número de macrófagos no LBA $(p=0,035)$ e na espessura do epitélio nasal $(p=0,042)$. Nossos dados sugerem que dose baixa de DEP induz inflamação do trato respiratório com padrão tempo-dependente.

Descritotes: poluição do ar, material particulado do diesel, epitélio nasal, nariz, pulmão, interleucinas, mucina-5ac, hiperplasia, camundongos. 


\section{Summary}

Yoshizaki K. Subchronic effects of diesel on nasal and airway epithelium in a murine model [Dissertação]. São Paulo: "Faculdade de Medicina, Universidade de São Paulo"; 2009.

Diesel exhaust is the major source of ultrafine particles (UFPs) in trafficrelated pollution. Subjects with chronic respiratory diseases have great risk of exacerbations during exposure to air pollution. This study evaluated the effects of sub-chronic exposure to a low dose of diesel exhaust particles (DEPs). Ninety male BALB/c mice were divided into 3 groups: (a) Control: nasal saline instillation ( $n=30)$; (b) DEP15: nasal instillation of $15 \mu \mathrm{g}$ of DEP/10 $\mu$ l of saline $(n=30)$; and (c) DEP30: nasal instillation of $30 \mu \mathrm{g}$ of DEP/10 $\mu$ l of saline $(n=30)$. Nasal instillations were performed five-days a week, during 30 e 60 days. Animals were anesthetized with pentobarbital sodium ( $50 \mathrm{mg} / \mathrm{kg}$ i.p), and sacrificed by exsanguination. Bronchoalveolar lavage $(B A L)$ was performed to assess inflammatory cell count and concetrations of interleukin (IL)-4, $-10,-13$ and -17 by enzyme-linked immunosorbent assay (ELISA). The RNAm MUC5ac gene expression was evaluated by real-time PCR. Histological analysis in nasal septum and bronchioles assessed: (a) bronchial and nasal epithelium thickness (b) acidic and neutral nasal mucous content. Our results showed that the instillation of DEP30 after 30 days increased the number of total inflammatory cells, as compared to the Control group $(p=0.033)$. The results of DEP30 after 60 days showed increases in: (a) the expression of MUC5AC in the lungs ( $p=$ 0.016); (b) acidic mucus production in the nasal septum ( $p=0.017)$; (c) total 
inflammatory cells in the BAL fluid ( $p<0.001$ ); (d) the number of macrophages in BALF $(p=0.035)$; and $(d)$ nasal epithelium thickness $(p=$ 0.042), as compared with control after 60 days. Our data suggest that a low dose of DEP induces inflammation of the respiratory tract in a timedependent manner.

Keywords: pollution air, particulate matter diesel, epithelium nasal, nose, lung, interleukins, mucin-5ac, hyperplasia, mice. 


\section{INTRODUÇÃO}

\section{Poluição e Saúde}

A poluição ambiental constitui um dos maiores problemas de saúde mundial, não apenas por sua influência da mudança climática do mundo, mas também por sua ação nociva na saúde humana. Mesmo em baixas concentrações, a associação entre os diferentes tipos de poluentes pode ser prejudicial à saúde (Becker et al, 1996). Estudos epidemiológicos têm demonstrado aumento da mortalidade, de hospitalizações, de atendimentos

emergenciais, no agravamento de doenças respiratórias e cardiorrespiratórias, e em alterações da função pulmonar em indivíduos sadios ou com doenças estabelecidas (Pope et al., 2004; Schwartz et al., 1994; Dockery et al., 1993).

Os efeitos da poluição do ar dependem não apenas de poluentes dispersos, mas ainda das condições atmosféricas, como intensidade luminosa, velocidade do vento, temperatura e do clima da região.

Combustíveis fósseis produzem um número de muitas substâncias prejudiciais à saúde, incluindo ambos componentes gasosos (orgânicos e inorgânicos) e componentes de particulados. Os mais deletérios destes últimos são os de diâmetro aerodinâmico menor que $2.5 \mu \mathrm{m}$, que são depositados no pulmão: alcançam o alvéolo, onde lá se depositam. Diferentes gases como o ozônio e sulfatos, e partículas dispersas como o material particulado, apresentam diferentes efeitos biológicos. A extensão 
dos efeitos dessas partículas depende da natureza das substâncias que a formaram - como seus componentes orgânicos e inorgânicos e metais - e do tamanho destas partículas (Tattersfield et al., 1996).

A formação do material particulado pode ocorrer da seguinte forma: durante a combustão de um produto fóssil pelas indústrias e veículos (incluindo desgaste de pneus) e a partir de material em suspensão da crosta terrestre que incluem materiais como poeira das estradas não-pavimentadas e operações de mineração, materiais biológicos como grãos de pólen e fragmentos de bactérias (Samet et al, 2005).

O material particulado compreende um complexo de elementos que se agregam, variando em tamanho e na composição química. De acordo com o tamanho, o material particulado (MP) pode ser classificado como: $\mathrm{PM}_{10}, \mathrm{PM}_{2,5}$, partículas finas $(<1 \mu \mathrm{m}$ de diâmetro) e as partículas ultrafinas $(<0,1 \mu \mathrm{m}$ de diâmetro). $\mathrm{O}$ tamanho das partículas determina o local do trato respiratório em que serão depositadas: partículas $\mathrm{PM}_{10}$ depositam-se principalmente no trato respiratório alto, ao passo que partículas finas e ultrafinas alcançam o alvéolo pulmonar. Os parâmetros importante das partículas na elucidação de seu efeito na saúde estão o tamanho e a superfície das partículas, que tem composições variadas adsorvidas, os metais e HPA (hidrocarbonetos pilicíclicos aromáticos), além de outros componentes orgânicos contribuem para a toxicidade do material particulado. (Kampa et al., 2007). 
Os motores a diesel são muito utilizados nos centros urbanos por sua robustez, economia proporcionada e pela durabilidade, e são considerados os maiores poluidores de ar nos centros urbanos (Salvi et al, 1999).

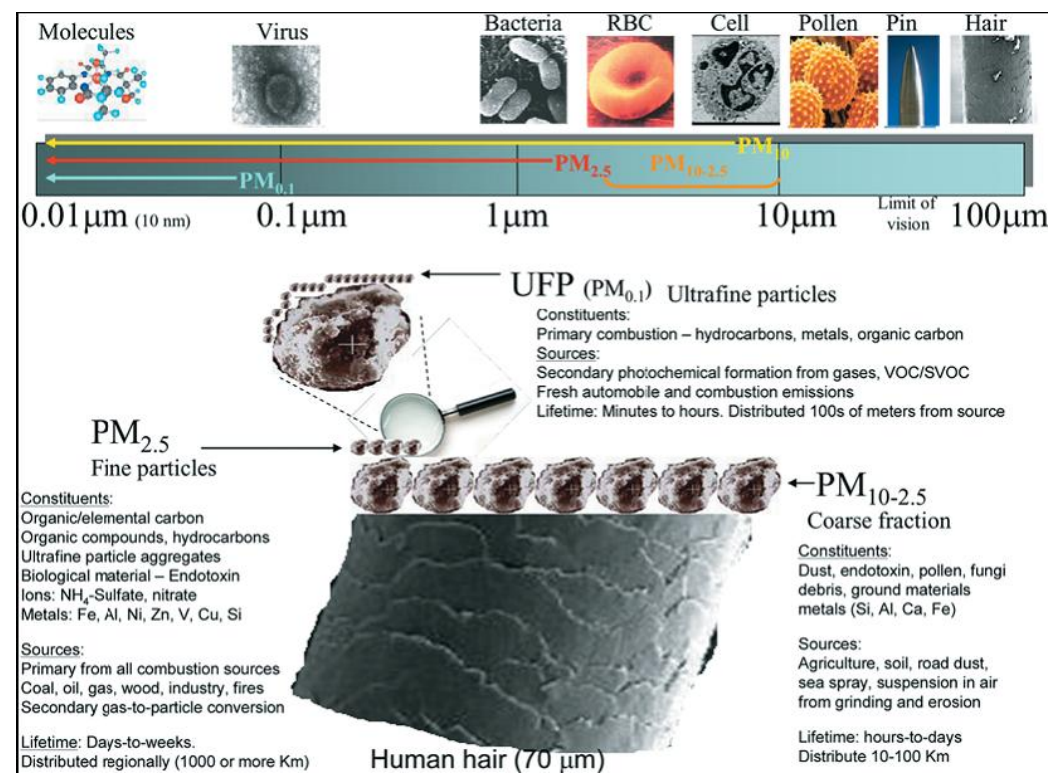

Figura 1. Tamanho e composição do material particulado da poluição do ar (Brook RD, 2008)

A composição das partículas de descarga de motores a diesel (Diesel Exhaust Particles - DEPs) pode variar de acordo com as diferenças climáticas e qualidade e tecnologia do motor. A combustão do diesel consiste numa mistura complexa de material particulado, incluindo elementos de carbono e hidrocarbonetos policíclicos aromáticos (HPAs), bem como aerossóis ácidos, compostos voláteis orgânicos, vários hidrocarbonetos, além de gases como dióxido de carbono (CO2), monóxido de carbono (CO), óxido nítrico (NO), dióxido de nitrogênio (NO2) e dióxido de enxofre (SO2). Após a combustão do diesel, os componentes da exaustão tende a se agregar em partículas respiráveis esféricas discretas de aproximadamente 0,1 a 0,5 $\mu \mathrm{m}$ de diâmetro (Pandya et al. 2002; Boland et 
al. 1999). Essas partículas são constituídas por um centro carbonáceo inerte com uma ampla área de superfície, ideal para adsorção de metais pesados e compostos orgânicos como HPAs. HPAs são pequenos compostos de 3 a 5 anéis de benzeno que podem facilitar a difusão através de membranas celulares (Peterson et al, 1996). Além disso, as DEPs contêm substâncias que são listadas como poluentes tóxicos do ar pela Agencia de Proteção Ambiental dos EUA (U.S.EPA, 1997).

A dose de partículas depositadas no pulmão dependem de sua concentração no ar inalado e de seu tamanho (Brain et al, 1979). Enquanto partículas inferiores a $5 \mu \mathrm{m}$ de diâmetro alcançam o alvéolo e lá se depositam, entretanto partículas maiores que $5 \mu \mathrm{m}$ somente alcançam a via aérea proximal e são eliminadas pelo transporte mucociliar (Sydbom et al, 2001). Considerando-se o DEP um desencadeador de reações inflamatórias

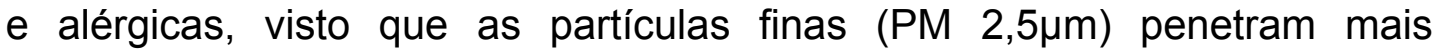
facilmente pelas vias aéreas e, consequentemente chegam até pulmões podendo causar complicações respiratórias e cardiorrespiratórias (Donaldson et al., 2003), o período de exposição está associado a alguns sintomas. A exposição aguda às partículas de exaustão de diesel (DEPs) causa alguns sintomas como irritação no nariz e olhos, dor de cabeça, alterações nas funções pulmonares e respiratórias, fadiga e náusea, enquanto a exposição crônica de DEPs induz à tosse, diminuição da produção de muco de septo e alteração na função pulmonar (Sydbom et al, 2001, Kanemitsu H et al, 1998, Sakakibara M et al, 1994). 
A exposição persistente a partículas de poluição do ar tem sido implicada como um dos fatores responsáveis pelo aumento da prevalência de doenças alérgicas (Takizawa, H 2004; Diaz-Sanchez D et al, 2003). Muitos estudos in-vivo e in-vitro tem associado DEPs à asma. (Peterson et al 1996, Devouassoux et al, 2002, Inoue et al 2007). Há hipóteses de que componentes da combustão do diesel levam a sintomas respiratórios em indivíduos com alergia ou asma preexistente, e alguns autores suportam a hipótese de que partículas da combustão do diesel podem ter papel principal na causa da asma (Pandya et al, 2002).

Com o objetivo de controlar as emissões da crescente fonte poluidora que é a gerada por veículos automotores, o Conselho Nacional de Meio Ambiente - CONAMA, criou em 1986, o Programa de Controle da Poluição do AR por Veículos Automotores - PROCONVE, definindo os limites máximos de emissão para todos os veículos novos, leves e pesados, nacionais e importados.

A deterioração da qualidade do ar na Região Metropolitana de São Paulo (RMSP) é decorrente das emissões atmosféricas de cerca de 2000 indústrias de alto potencial poluidor e da frota registrada de aproximadamente 9,2 milhões de veículos. Esta é composta por 7,4 milhões de veículos com motores do ciclo Otto, (movidos a gasolina e/ou álcool), 490 mil veículos a diesel e 1,2 milhões de motos, representam cerca de 1/5 do total nacional. De acordo com as estimativas de 2008, essas fontes de poluição são responsáveis pelas emissões para a atmosfera dos seguintes poluentes: 1,56 milhão de toneladas lano (t/ano) de monóxido de carbono, 
387 mil t/ano de hidrocarbonetos, 367 mil t/ano de óxidos de nitrogênio, 62,3 mil t/ano de material particulado total e 25,5 mil t/ano de óxidos de enxofre. Desses totais, os veículos são responsáveis por $98 \%$ das emissões de CO (monóxido de carbono), $97 \%$ de $\mathrm{HC}$ (hidrocabonetos), $96 \%$ de $\mathrm{NO}_{x}$ (óxido de nitrogênio), $40 \%$ de MP (material particulado) e 33\% de $\mathrm{SO}_{x}$ (óxido de enxofre). (Relatório da CETESB, 2008).

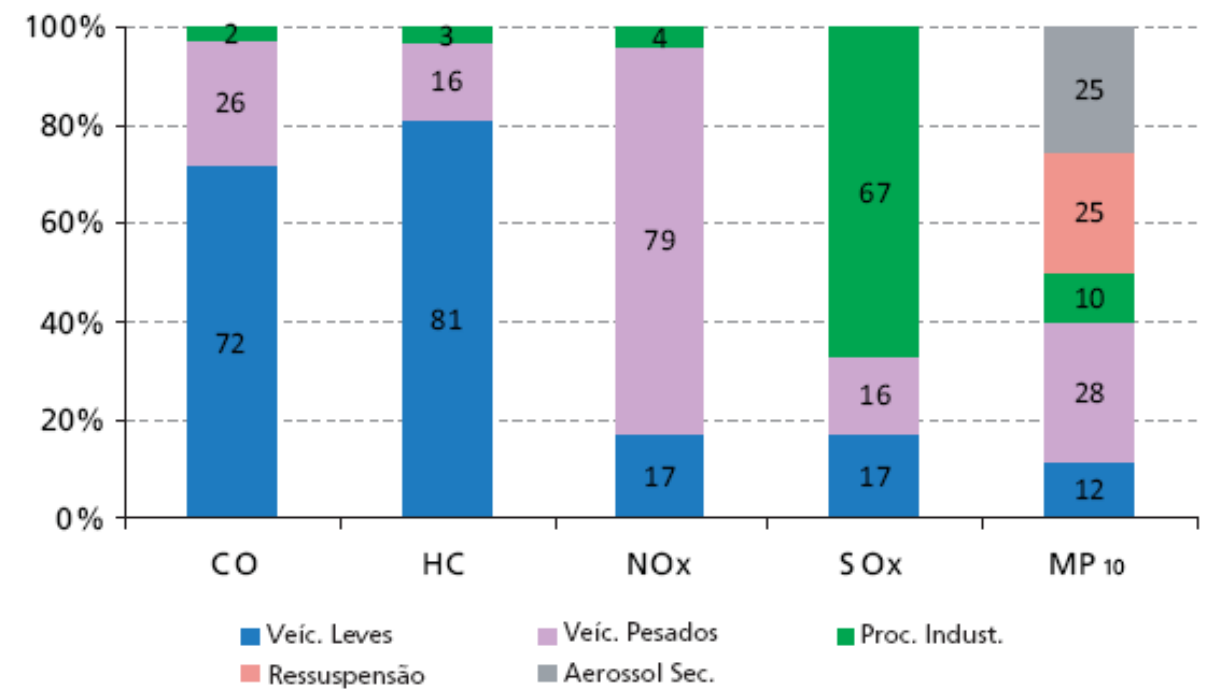

Figura 2. Emissões relativas de poluentes por tipo de fonte (CETESB, 2008)

\section{Trato Respiratório}

A via aérea do trato respiratório é conhecida pela sua função no papel crítico na manutenção da integridade da mucosa, e como barreira mecânica contra vários agentes nocivos (Takizawa $H, 1998)$. Devido as suas características anatomofuncionais, o sistema respiratório é frequentemente o maior alvo dos contaminantes presentes no ar atmosférico. A importância desse sistema vai além das trocas gasosas entre o ar e sangue; também 
tem funções não-respiratórias, como na manutenção de um sistema imunológico ativo e do metabolismo de substâncias endógenas.

\section{Vias Aéreas Superiores (Trato Respiratório Proximal) e Epitélio Nasal}

A primeira porção do sistema respiratório ao entrar em contato com o meio externo e, consequentemente, com a poluição atmosférica, é o nariz (Schawab et al, 1998), que é a primeira barreira mecânica contra vários agentes nocivos inalados (Takizawa et al, 1998). O nariz faz parte da região condutora do sistema respiratório e tem como principais funções filtrar, aquecer e umidificar o ar inspirado (Guyton \& Hall, 1998), por meio de um sistema para remover partículas e microorganismos, o aparelho mucociliar (Knowles \& Boucher, 2002). Considerando-se o papel da mucosa nasal e sua importância para o sistema respiratório, alterações estruturais significantes na mucosa nasal exposta à poluição do ar tem sido reportadas em humanos e em animais (Pires-Neto et al., 2006) A exposição prolongada a um baixo nível de poluição de ar ambiente mostra evidências de alteração na secreção da cavidade nasal de camundongos, com aumento de muco ácido (Pires-Neto et al, 2006). A exposição prolongada à poluição do ar causada por motores veiculares é considerada um dos fatores principais do aumento na prevalência de doenças alérgicas nasal como rinite (Li et al., 2003). 
Em humanos, a parte condutora do sistema respiratório é revestida pelo epitélio respiratório do tipo pseudoestratificado, caracterizado pela presença de células ciliadas colunares e numerosas células caliciformes. Também estão presentes células basais, células em escova (Junqueira \& Carneiro, 2004).

A célula ciliada colunar é a mais freqüente e possui em média 300 cílios em sua superfície apical. Em segundo lugar vêm as células caliciformes, secretoras de muco, com numerosas quantidades de muco composto de glicoproteínas em sua parte apical (Junqueira \& Carneiro, 2004).

Em camundongos, a cavidade nasal está dividida longitudinalmente em narinas, concha nasal, concha maxilar, concha etmoidal, faringe (nasofaringe, orofaringe, epiglote e laringofaringe) e laringe. $O$ septo nasal separa a cavidade nasal em duas metades semelhantes. É constituído de por tecido cartilaginoso, e, ao contrário do dos humanos, o septo nasal não separa totalmente as metades da cavidade nasal: um pequeno espaço em sua base anteriormente ao ducto nasofaríngeo permite comunicação direta entre os compartimentos e serve de caminho para a nasofaringe. Esse espaço também serve de ponto de convergência para os fluxos de ar e de muco (Hebert e Leininger, 1999).

Quatro tipos de epitélio revestem a cavidade nasal dos camundongos. Da porção anterior para a posterior, o epitélio muda de estratificado pavimentoso para respiratório e então para olfatório, com estreitas zonas de transição entre cada tipo de epitélio. Um epitélio de transição com poucos 
cílios existe entre o epitélio pavimentoso e o respiratório na região proximal. A superfície recoberta pelos epitélios pavimentoso, respiratório e olfatório na cavidade nasal de camundongos é, respectivamente, de $7 \%, 46 \%$ e $47 \%$ (Herbert e Leininger, 1999).

Animais vêm sendo utilizados como modelo experimental através por meio da técnica de instilação nasal, (Medeiros et al., 2004; Laks et al, 2008; Zanchi et al., 2008), que se mostrou excelente para estudos de poluição em murinos.

\section{Vias Aéreas Inferiores (Trato Respiratório Distal)}

O brônquio é um dos componentes das vias respiratórias e participa do mecanismo de defesa do trato respiratório: através do sistema mucociliar, contra agentes nocivos presentes no ar atmosférico (Konietzko, 1986). Os bronquíolos não são formados de anéis cartilaginosos, mas por tecido conjuntivo.

Em camundongos, o pulmão esquerdo apresenta um lobo e o direito quatro lobos: cranial, médio, caudal e acessório (Heldrich, 2004). Difere do humano, que apresenta o pulmão esquerdo dividido em lobo superior e inferior, e o pulmão direito em lobos superior, médio e inferior.

As grandes vias aéreas de camundongos são formadas por células colunares, células de Clara, células ciliadas, células neuroendócrinas, células mucosas e celulas em escova (Heldrich, 2004). As pequenas vias 
aéreas do camundongo são os bronquíolos terminais com abertura nos ductos alveolares, que terminam em sacos alveolares e alvéolos.

\section{Mecanismos de defesa pulmonar}

Os mecanismos de defesa pulmonar envolvem todos os processos de defesa do pulmão contra as agressões advindas do meio externo. Os pulmões são protegidos por um conjunto de mecanismos de defesa interativos, que inclui defesas mecânicas, químicas e imunológicas. O maior grau de proteção pulmonar é atingido quando a ação de todos os mecanismos disponíveis é coordenada (Rennard \& Romberger, 2000).

Dentre esses mecanismos ressalta-se a filtração aerodinâmica das partículas inaladas. As partículas possuem capacidades diferentes para percorrer o trato respiratório, dependendo de tamanho, densidade e forma. A impactação é mecanismo de filtração aerodinâmica particular, que depende da inércia das partículas. Impactação inercial que é a tendência da partícula seguir sempre em linha reta, e promove colisões com as paredes do trato respiratório devido as bifurcações; sedimentação gravitacional é a deposição das partículas pela redução do fluxo de ar nas vias aéreas; e o movimento Browniano que fazem com que as moléculas de gases desloquem as partículas ao acaso até que entrem em contato com as paredes das vias aéreas e lá se depositem.

$\mathrm{Na}$ eliminação das partículas no trato respiratório, o aparelho mucociliar é o responsável pela depuração das partículas inaladas que se 
depositam na camada de muco que recobre as vias aéreas. O perfeito funcionamento do transporte mucociliar depende de fatores relacionados aos cílios, ao muco e à interação adequada entre ambos, sendo necessária a preservação das propriedades fisicoquímicas do muco secretado e da função do batimento ciliar. Muitos são os fatores que podem interferir no bom funcionamento desse mecanismo, destacando-se o fumo, as infecções e a poluição-

O muco respiratório é uma mistura complexa de macromoléculas, eletrólitos e água, além de outros componentes como as substâncias antioxidantes, tampões, imunoglobulinas e enzimas, que são capazes de interagir com microorganismos, e outras substâncias oxidantes e inflamatórias, como lisozima, lactoferrina e diversas peroxidases. As glicoproteínas conferem as propriedades mecânicas e fisicoquímicas do muco respiratório (Lorenzi, et al.,1995).

Quanto ao revestimento das vais aéreas, o muco é composto por duas fases: (i) epifase gel, mais viscosa, descontínua em diversos pontos, pela ação do batimento ciliar e secretada pelas glândulas mucosas e pelas células caliciformes do epitélio e (ii) hipofase sol, atualmente denominada de liquido periciliar (LPC), menos viscoso, recobrindo continuamente as vias aéreas, desde a traquéia até os bronquíolos. O LPC é produzido pelas células secretoras serosas glandulares e pelas células de clara do epitélio e, por transdução a partir dos vasos que irrigam as vias aéreas (Jiang et al., 1993). O controle da secreção da hipofase sol é fundamental para o bom funcionamento do transporte ciliar, de forma a manter os cílios em contato 
ideal com a epifase gel. Um aumento ou uma diminuição da espessura da hipofase sol promove o desacoplamento entre o cílio e o muco. (Sleig, 1988; Satir \& Sleig, 1990). A diminuição da camada sol ou periciliar prejudica o funcionamento adequado do cílio e o transporte de muco (Bouquit et al., 2002). Esse é o caso na fibrose cística, que apresenta alteração do volume no fluído superficial das vias respiratórias, afetando o funcionamento adequado no movimento ciliar.

O transporte ciliar também pode ser prejudicado pelas alterações das propriedades reológicas do muco, as quais determinam a relação entre viscosidade e elasticidade da secreção brônquica. As propriedades reológicas são determinadas, em síntese, por sua composição bioquímica, pela compactação do arranjo quaternário das moléculas e por hidratação. Essa estrutura macromolecular é determinada por ligações dissulfeto intra e intermoleculares, bem como por ligações o-glicosídicas entre os açúcares que compõem as glicoproteínas. Além disso, o grau de hidratação do muco, o teor de outras macromoléculas acopladas ao muco (imunoglobulinas, DNA, etc), o pH e a composição iônica do meio, interferem no arranjo espacial das moléculas de glicoproteínas. Estes alteram, consequentemente, seu comportamento mecânico, o qual deveria estabelecer a existência de um componente elástico capaz de transmitir com eficiência a energia do cílio ao muco, e de um componente viscoso, de forma a permitir a movimentação de partículas por meio da ação dos cílios ou tosse (Lorenzi et al., 1992). 
A existência de um componente elástico (ligações estáveis - pontes de dissulfeto e O-glicosídicas) e de um componente deformável, viscoso, representado pelas ligações menos estáveis (interações iônicas), permite que o muco não se comporte como um líquido newtoniano, puramente viscoso e perfeitamente elástico, mas sim como um fluido não-newtoniano (Stair \& Sleig, 1990; Lorenzi et al., 1992).

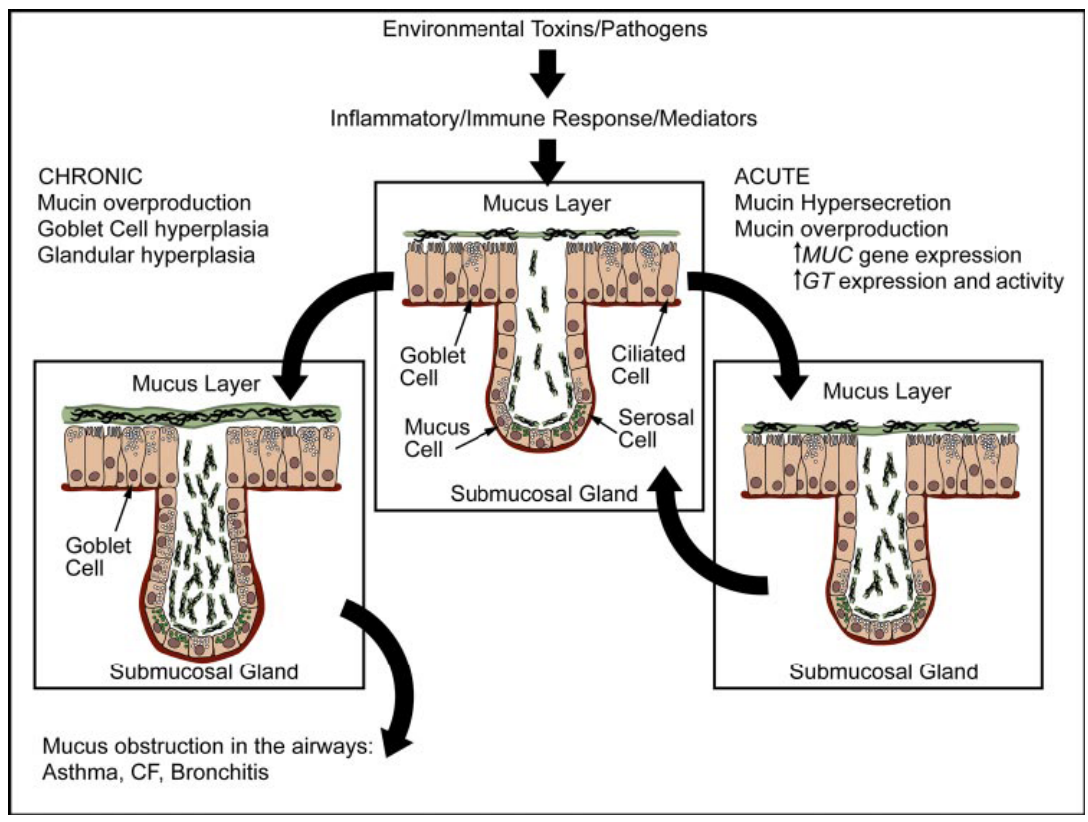

Figura 3. Resposta das células secretoras das vias aéreas para eventos agudos ou crônicos (Rose et al, 2006)

Respostas imune inflamatórias/mediadores são geradas no pulmão após a exposição de epitélio humano normal a irritantes ambientais, a figura 3 esquematiza as respostas das células secretoras das vias aéreas para eventos agudos e crônicos. (Rose et al, 2006). 


\section{Expressão de Genes de mucina}

As mucinas da via aérea são os maiores componentes da camada solúvel e/ou viscoelástica que compreende o muco pulmonar na via aérea saudável e contribuem para a defesa mucociliar que protege os pulmões contra patógenos e toxicinas ambientais (Rose et al, 2006).

Desde 1992, o número de genes de mucinas identificadas no genoma humano aumentou de 4 para 21. Há pelo menos 20 tipos diferentes de genes de mucina no corpo humano, mas as principais encontradas no epitélio das vias aéreas respiratórias distais são: MUC1, MUC2, MUC4, MUC5AC, MUC5B, MUC7, MUC8, MUC11, MUC13, MUC19, e MUC20. Já as localizadas no pulmão podem ser divididas em três grandes famílias de mucinas: (i) as formadoras da camada gel (MUC2, MUC5AC, MUC5B, MUC19), (ii) as associadas à membrana, que podem funcionar como receptoras de membrana (MUC1, MUC4, MUC11, MUC13, MUC20), e (iii) as secretadas não-formadoras de gel (MUC7, MUC8) (Willians et al, 2006).

A MUC5AC é uma mucina secretora, classificada como traqueobrônquica, produzida pelas células mucosas na superfície do epitélio (Awaya H, et al., 2004, Wickstrom C, et al., 1998; Hovenberg, HW et al., 1996). É codificada no cromossomo 11p15, possui peso molecular de 105 para 107 kd e tem um papel na proteção de células contra substâncias nocivas exógenos. O gene do MUC5AC é o principal componente da secreção respiratória e vários estudos relatam que o nível do RNAm do MUC5AC estão aumentados no tecido brônquico de pacientes com asma e em inflamações de um modo geral. (Reid, 1997; Willians et al, 2006). Sabe- 
se que vários estímulos, como a inalação ou instilação a alérgenos, vírus, elastase, neutrófilos e várias citocinas também induzem a superprodução dessa mucina. O desenvolvimento do fenótipo mucoso a partir dessas condições tem mostrado uma mudança para metaplasia de células mucosas, bem como hiperplasia dessas células. A metaplasia não parece ocorrer por meio de proliferação, uma vez que acontece uma substituição do tecido diferenciado maduro para outro tipo de tecido diferenciado sem o aumento do número de células. Já a hiperplasia de células mucosas envolve mudanças devido à proliferação celular com aumento do número total de células dentro do tecido (Willians et al., 2006).

A produção de mucinas na via aérea de camundongos alérgicos pode ocorrer na presença ou na ausência do aumento da proliferação epitelial, dependendo da natureza ou frequência de estímulos inflamatórios, indicando que o mecanismo mitótico pode acompanhar, mas não ser obrigatório, para a diferenciação do muco. Em camundongos, a produção de mucinas na superfície epitelial ocorre dentro das células de Clara presente na via aérea e pode ser identificada pela expressão de proteínas secretoras nessas células. Em humanos saudáveis, as células mucosas estão presentes dentro do epitélio pseudoestratificado colunar de via aérea brônquica numa extensão que vai até os bronquíolos periféricos. O muco em bronquíolos humanos (<2 mm de diâmetro de via aérea) também é encontrado em células de Clara, indicando que a indução da expressão de mucina pelas células de Clara em humanos pode ser um importante mecanismo de super 
produção de muco na via aérea pequena sob condições de doença (Willians et al, 2006).

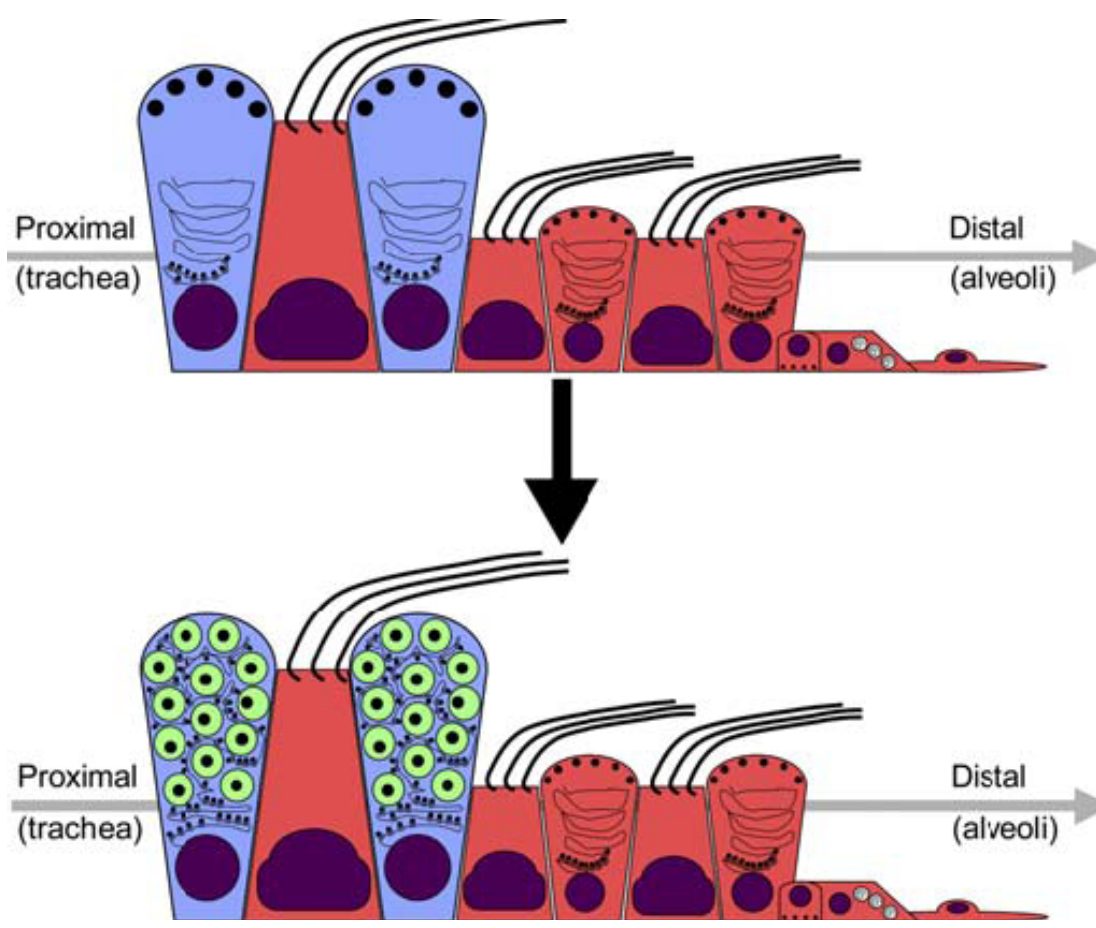

Figura 1. Regulação temporal e espacial da expressão do gene de mucina na via aérea (Williams et al., 2006)

A via aérea de camundongo apresenta um epitélio colunar que consiste de células ciliadas e não-ciliadas. As células não-ciliadas são secretoras além das caliciformes expressam marcadores para células de Clara que contêm o reticulo endoplasmático. Após estimulação alérgica, há uma alteração na morfologia de células não-ciliadas do epitélio da via aérea proximal (azul) (figura 3), caracterizada pelo aumento na atividade de conteúdos de produtos de secreção no retículo endoplasmático rugoso, e expressão de mucinas que ocorre durante o processo de diferenciação (Williams et al, 2006) . 


\section{Componentes da resposta inflamatória e mediadores químicos}

O sistema imunológico engloba processos inflamatórios de interação célula-célula. Estes envolvem mecanismos diferenciados que resultam na eliminação dos agentes invasores: imunidade inata ou adaptativa. Os principais componentes da imunidade inata são barreiras físicas e químicas, como o epitélio mucociliar e substâncias antimicrobianas produzidas em superfícies epiteliais e células fagocíticas (mononucleares: macrófagos, monócitos e polimorfonucleares) (Abbas et al., 2003).

\section{Citocinas}

Respostas envolvidas na fase aguda e crônica e resposta imune inespecífica são resultados de um complexo processo envolvendo vários mediadores químicos, dentre eles as citocinas. A maioria das citocinas é composta por polipepitídeos simples ou glicoproteínas com peso molecular igual ou inferior a $30 \mathrm{kDa}$. A produção é regulada por vários estímulos indutores em nível de transcrição ou tradução das citocinas. As ações reguladas pelas citocinas são de curta duração, via receptores específicos localizados na superfície celular. As citocinas anti-inflamatorias são moléculas imunorreguladoras que controlam as respostas das citocinas inflamatórias. A IL-10 é uma importante citocina anti-inflamatória na resposta imune (Clarke et al, 1998). 
A relação entre DEP e alergia vem sendo focada em alguns estudos. Trabalhos de cultura de célula e estudos em animais têm demonstrado que sensibilidade a alérgenos e desenvolvimento de respostas alérgicas podem ser causadas pelo aumento de variedades de poluentes no ar, mais proeminentemente pela partícula de DEP. Estudos de Diaz-Sanches e colaboradores, com instilação de partículas de DEP no nariz (Medeiros et al., 2004; Laks et al, 2008; Zanchi et al., 2008), sugerem que DEP pode tanto aumentar a resposta alérgica como promover a sensibilização a novos alérgenos no nariz. (Pourazar et al, 2004).

Numerosos estudos têm demonstrado que componentes específicos da poluição atmosférica podem estar associados à exacerbação da asma, sendo esta uma doença de manifestação de hiperresponsividade brônquica, constrição brônquica reversível, inflamação de vias aéreas e mecânica respiratória alterada. Existem algumas evidências epidemiológicas associando níveis altos de exaustão de diesel à asma. Numerosos componentes da exaustão de diesel são irritantes respiratórios, incluindo aerossóis ácidos, componentes orgânicos voláteis e gases na mistura. Esses efeitos irritantes em si poderiam potencialmente deflagrar sintomas asmáticos para níveis de exposição relativamente aceitáveis (Boland et al, 1999).

Uma cascata imunológica complexa, incluindo um recrutamento de células inflamatórias da corrente sanguínea (linfócitos T, mastócitos, eosinófilos e macrófagos) para a mucosa brônquica é uma característica da asma (Pandya et al, 2002), liberando citocinas, quimocinas e mediadores 
citotóxicos por essas células e por células epiteliais, fibroblastos, e células de músculo liso.

Linfócitos T parecem desempenhar um papel importante particular na inflamação da via aérea. As células $T$ ou linfócitos $T$ ( $T$ helper) liberam citocinas específicas que, por sua vez, liberam mediadores inflamatórios. Células tipo TH1 produzem interferon gama, interleucina-2 (IL-2) e fator tumoral de necrose $\beta$ (TNF- $\beta$ ), e células do tipo TH2 produzem IL-4, IL-5, IL6, IL-10 e IL-13. Algumas citocinas como o IL-1, IL-3, IL-8, TNF- $\alpha$ são produzidas por $\mathrm{TH} 1$ e TH2. As células $\mathrm{TH} 2$ estão relacionadas com a produção de substâncias sinalizadoras que têm relação com resposta asmática mais fortemente que as TH1 (Pandya et al, 2002). IL-13 e IL-4, por exemplo, são citocinas produzidas por células TH2 e estas aumentam a densidade de células caliciformes, expressão do gene de mucina, glicolização da mucina e secreção de muco, sendo esta última atividade crítica para promover a patologia da asma. IL-10 é produzido por células tipos $T$, incluindo CD4+, CD5+ reguladoras de celulas $T$, que são capazes de regular a resposta alérgica no pulmão. Alguns estudos mostram a importância de IL-10 na resolução da inflamação da via aérea e na hiperrresponsividade da via aérea (Kearley et al, 2005). IL-17 é uma molécula pró-inflamatórias encontrada em pacientes asmáticos. No estudo de Song et al. (2008) relataram que os macrófagos, em vez de células Th17 são o principal produtor de IL-17 na inflamação alérgica relacionada à asma (Song et al. 2008). 
Estas substâncias, agindo em conjunto ou isoladamente, direcionam o recrutamento e a ativação de outras células inflamatórias às vias aéreas.

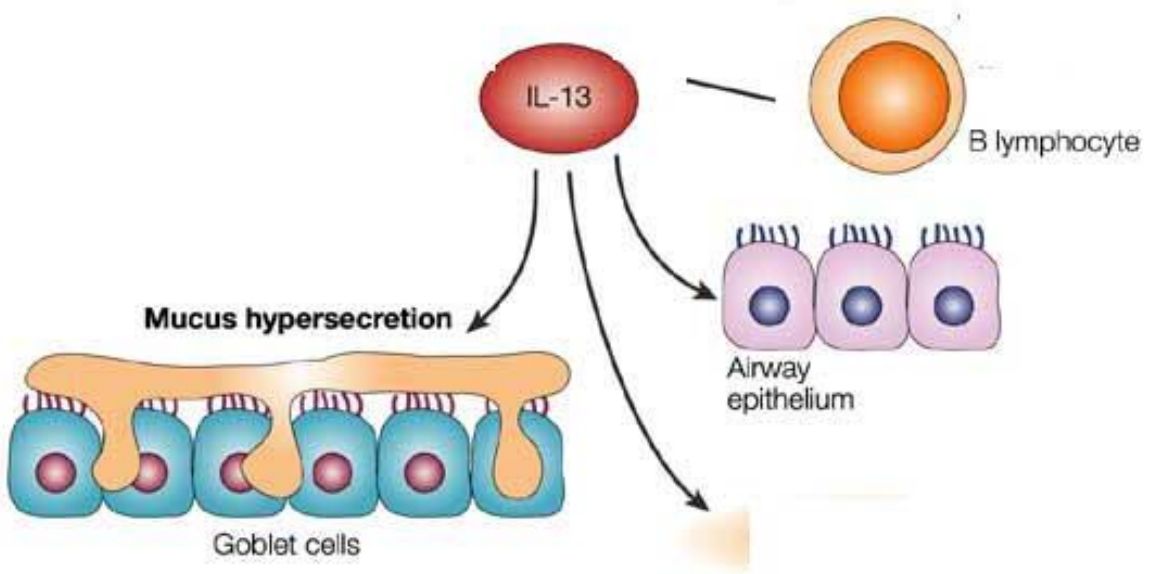

Figura 2. Representação da interleucina-13 (IL-13)

Tabela 1- Relação de algumas interleucinas relacionadas à origem e participação na inflamação.

\begin{tabular}{|l|l|l|}
\hline Mediadores & Origem & Ações \\
\hline IL-4 & Linfócitos T, mastócitos & $\begin{array}{l}\text { Ativação de linfócitos B, } \\
\text { supressão De linfócitos Th2. }\end{array}$ \\
\hline IL-10 & Linfócitos T, mastócitos & $\begin{array}{l}\text { Potente supressor da função } \\
\text { do macrófago, inibição da } \\
\text { síntese de citocinas pró- } \\
\text { inflamatorias. }\end{array}$ \\
\hline IL-13 & Linfócitos T & $\begin{array}{l}\text { Induz na formação de } \\
\text { células secretoras, } \\
\text { hipersecreção de muco }\end{array}$ \\
\hline IL-17 & macrófagos & $\begin{array}{l}\text { Ativa células T, aumenta o } \\
\text { número de neutrófilos, induz } \\
\text { IL-6, TNFa e TGF- } \beta\end{array}$ \\
\hline
\end{tabular}




\section{Relevância dos parâmetros biológicos em estudos de poluição}

Parâmetros laboratoriais e teciduais podem ser utilizados para avaliação dos efeitos biológicos da exposição aos agentes poluentes. Em nosso estudo utilizaremos alguns parâmetros para avaliar a resposta ao agente poluente: Lavado bronchoalveolar para indentificação de células inflamatórias (macrófagose, neutrófilos, linfócitos e eosinófilos) e concentração de interleucinas no sobrenadante do lavado bronchoalveolar (IL)-4, IL-10, IL-13 e IL-17) por "Enzyme-linked immunosorbent assay" (ELISA); expressão genica de mucina em "real time-PCR" MUC5ac em tecido pulmonar; e análise histologica de septo nasal e bronquiolos para determinação de espessura de epitelio; e conteudo de muco acido e neutro no septo nasal. Foram avaliados o efeito da instilação nasal de duas concentrações de material particulado do diesel (DEP) 15 e $30 \mu \mathrm{g}$ em $10 \mu \mathrm{l}$ de solução salina durante dois periodos de exposição (exposição subcrônica) em camundongos BALB/c. 


\section{OBJETIVOS}




\section{OBJETIVOS}

Este trabalho visa estudar o efeito da exposição subcrônica ao particulado de diesel na resposta inflamatória em dois segmentos do trato respiratório de camundongos: proximal (septo nasal) e distal (bronquíolos).

Os seguintes parâmetros serão utilizados para avaliar a resposta ao agente poluente:

(i) Células inflamatórias por meio de lavado bronchoalveolar para indentificação de macrófagos, neutrófilos, linfócitos e eosinófilos;

(ii) concentração de interleucinas no sobrenadante do lavado bronchoalveolar IL-4, IL-10, IL-13 e IL-17 por imunoensaio Elisa (Enzymelinked immunosorbent assay);

(iii) expressão gênica de mucina: MUC5ac em RNAm, por meio do método de detecção de seqüência ou $\mathrm{PCR}$ em tempo real (real time-PCR) em tecido pulmonar;

(iv) análise histológica de septo nasal e bronquíolos para determinação de espessura de epitélio;

(v) conteúdos de muco ácido e neutro no septo nasal.

Esses parâmetros permitiram avaliar o efeito da instilação nasal de

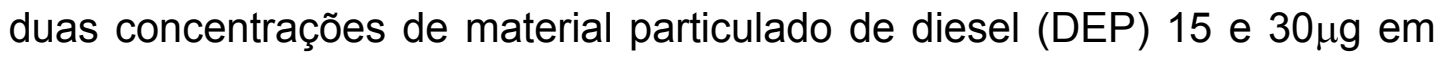
$10 \mu \mathrm{l}$ de solução salina durante dois períodos de exposição (exposição subcrônica) em camundongos BALB/c. 


\section{MATERIAIS E MÉTODOS}

\section{Comissão de Ética}

Todos os estudos apresentados foram aprovados pelo Comitê de

Ética para Pesquisa da Faculdade de Medicina da Universidade de São Paulo (CAPPesq-FMUSP), Protocolo n0 0571/08.

\section{Animais}

Foram utilizados como bioindicador dos efeitos inflamatórios 90 camundongos machos da linhagem Balb/c, adultos jovens, com 08 semanas de idade, pesando aproximadamente $15-20 \mathrm{~g}$. Os animais foram obtidos do Biotério Central da Faculdade de Medicina da Universidade de São Paulo e mantidos em condições controladas de temperatura $\left(22-25^{\circ} \mathrm{C}\right)$ e luminosidade (ciclo $12 \mathrm{~h}$ claro/12h escuro), e $70 \%$ de umidade relativa. A alimentação constou de água e ração (Purina Labina®, São Paulo, Brasil) "ad libitum".

\section{Coleta do Material Particulado do Diesel}

Neste estudo pretendemos avaliar o material partículado do diesel, coletados com retentor de partículas que esta sendo testado em veículos a diesel com intuito de reduzir a emissão do material particulado no ar de São Paulo. Ele é constituído de um filtro bi-metálico que cria um campo capaz de reter o material particulado que é emitido do escapamento do ônibus a diesel. 
As de partículas enxofre contidas no diesel foi de 500 partes por milhão (ppm) de enxofre, e foram coletadas no ano de 2006, após 1 dia de operação de rotina de um ônibus da frota metropolitana da cidade de São Paulo. Este ônibus era equipado com um motor Mercedes Benz MB1620, 210-hp, com perfil de emissão Euro III, injeção elétrica, sem tratamento de emissões no tubo de escape e armazenados em geladeira a $4^{\circ} \mathrm{C}$ para estudos toxicológicos. As características das DEPs foram analisadas de acordo com: a) as concentrações de metais, que foram determinadas por uma energia dispersiva de espectrometria de fluorescência de raios-x em ppm, e b) as concentrações de hidrocarbonetos policíclicos aromáticos (HPAs) (ng/g), determinado por espectrofotometria de absorção atômica, cujos valores (média \pm DP) são apresentados na Tabela 2 (Laks et al., 2008). Suspensões de DEP foram preparadas pela dissolução de $10 \mathrm{mg}$ desta partícula em $1,0 \mathrm{ml}$ de solução salina. As concentrações de DEP preparadas foram: a) $15 \mu \mathrm{g}$ de DEP diluído em $10 \mu \mathrm{l}$ de solução salina; b) $30 \mu g$ de DEP diluído em $10 \mu$ l de solução salina.

\begin{tabular}{lccc}
$\begin{array}{l}\text { TABELA 2. Conteúdo de Metais } \\
\text { Aromáticos }(\mathbf{p p m})\end{array}$ & e Hidrocarbonetos & Policíclicos \\
\multicolumn{1}{c}{ Metais } & DEP & HPAs & DEP \\
\hline Níquel (Ni) & $0.181 \pm 0.037$ & Naftaleno & 49.23 \\
Enxofre (S) & $0.626 \pm 0.416$ & Acenafitaleno & 179.48 \\
Ferro (Fe) & $74.556 \pm$ & Fluoreno & 683.94 \\
Vanádio (V) & $0.037 \pm 0.013$ & Antraceno & 94.73 \\
Chumbo & $0.050 \pm 0.047$ & Pireno & 12838.27 \\
Cádmo (Cd) & $0.029 \pm 0.008$ & Benzo[a]antraceno & 1162.73 \\
Cromo (Cr) & $0.161 \pm 0.116$ & Benzo[b]fluorateno & 789.93 \\
Cobrer (Cu) & $0.017 \pm 0.001$ & Benzo[k]fluorateno & 562.28 \\
& & Benzo[a]pireno & 1642.28
\end{tabular}

Concentração de metais foi determinada por espectometria de raio-x e a concentração de hidrocarbonetos policíclicos aromáticos (HPAs) foi determinada por espectometria de absorção atômica. Valores em média \pm DP. (Laks et al, 2008) 


\section{Grupos Experimentais e Administração da Solução Teste}

Os experimentos laboratoriais tiveram início com a exposição dos animais pela instilação nasal (aspiração involuntária) em ambas as narinas do animal por meio de uma pipeta automática. As concentrações de material particulado do diesel foram $15 \mu \mathrm{g}, 30 \mu \mathrm{g}$ (diluído em $10 \mu \mathrm{l}$ de solução salina-5 $\mu$ l em cada narina) e o grupo Controle recebeu somente instilação com solução salina. Os experimentos foram realizados no LIM 05 (Laboratório de Poluição Atmosférica), e a exposição através da instilação nasal foi realizada diariamente durante cinco dias consecutivos por 30 e 60 dias. Os grupos foram os seguintes:

Período de 30 dias de exposição:

- Grupo controle que recebeu instilação de solução salina $(n=15)$;

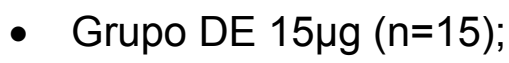

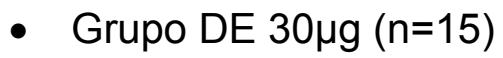

Período de 60 dias de exposição:

- Grupo controle que recebeu instilação de solução salina $(n=15)$;

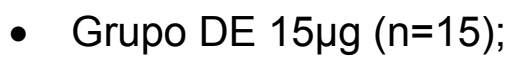

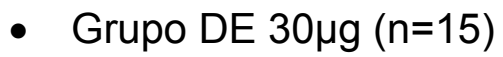

Os animais foram sacrificados após 24 horas da última instilação do período de intoxicação do DEP, o animal foi anestesiado com $3 \%$ de pentobarbital de sódio (30 mg/kg de peso por injeção intraperitoneal). Após isto, o animal foi eutanasiado por secção da aorta abdominal e exsangüinação. 
Para análise de expressão de gene de MUC5ac, foram utilizados 7 pulmões de cada grupo que foram retirados após a eutanásia de cada animal e armazenados em tubos para criopreservação e transportados em nitrogênio liquido. Os 8 pulmões restantes de cada grupo foram realizados lavado broncoalveolar e após fixados em formalina tamponada para realização da morfometria que será descrito mais adiante. A cabeça foi removida, a mandíbula desarticulada, colocada em formol tamponado por 24 horas e depois colocada em EDTA para descalcificação para analise morfométrica do septo nasal.

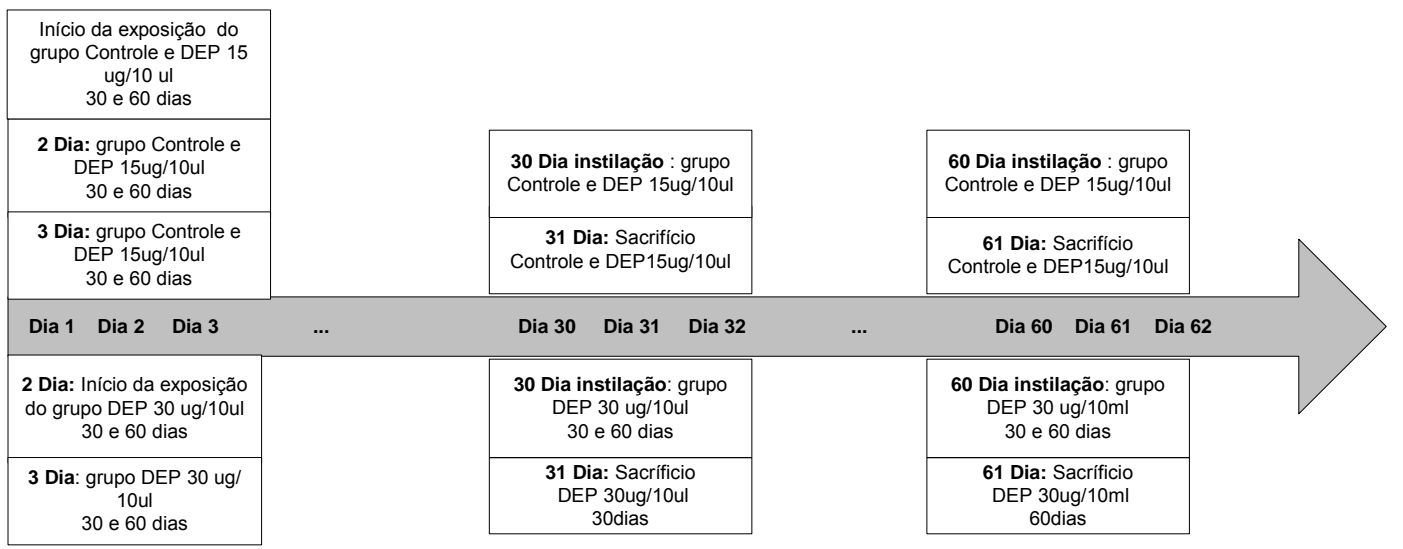

Figura 6: Fluxograma representando o período de instilação intranasal de DEP de concentrações $15 \mu \mathrm{g}$, 30 $\mu \mathrm{g}$ (diluído em $10 \mu \mathrm{l}$ de solução salina) e solução salina (grupo Controle) nos animais. 


\section{Obtenção das células inflamatórias: Coleta e Análise do Lavado Broncoalveolar (LBA)}

Para a realização do lavado broncoalveolar (LBA) fez-se uma traqueostomia e em seguida foi introduzida uma cânula traqueal. $0,5 \mathrm{~mL}$ de Tampão Fosfato Salina (PBS) foi infundida na traquéia, por 3 vezes consecutivas, totalizando um volume de $1,5 \mathrm{~mL}$. O volume recuperado foi centrifugado a $1810 \mathrm{rpm}$, a $5^{\circ} \mathrm{C}$, por 10 minutos. $O$ sobrenadante foi guardado em tubos eppendorf e congelado em freezer $-70^{\circ} \mathrm{C}$ para análise de interleucinas. O pellet foi ressuspendido em $300 \mu \mathrm{l}$ de PBS. Com $10 \mu \mathrm{l}$ foi feita a contagem total de células totais através de microscopia ótica com o hemocitômetro de Newbauer em aumento de 400X.

Para a contagem diferencial, $100 \mu \mathrm{l}$ do LBA foi ressuspemdido em $300 \mu \mathrm{l}$ de PBS e citocentrifugados a 450 rpm por 6 minutos e após a lâmina seca, esta foi corada pelo corante Giemsa. A contagem diferencial das células foi determinada a partir do achado de pelo menos 300 leucócitos/lâmina e a diferenciação seguiu os critérios hemocitológicos para diferenciação de neutrófilos, eosinófilos, linfócitos e macrófagos com o auxílio de um microscópio ótico com objetiva de imersão (1000X) (van Rijt et al., 2004)

\section{Quantificação de mediadores inflamatórios}

As citocinas IL-4, IL-10, IL-13 e IL-17 foram quantificadas por ELISA, através de Kits Duo Set $\left(R \& D\right.$ System $\left.{ }^{\circledR}\right)$, disponíveis comercialmente, em 
alíquotas do sobrenadante do LBA pulmonar, obtidas de acordo com o item acima. Os ensaios foram conduzidos seguindo as especificações do fabricante. Limites de detecção IL-4 (2 - 125 pg/ml), IL-10 (31.3 - 2000 $\mathrm{pg} / \mathrm{ml}), \mathrm{IL}-13(15.6$ - $1000 \mathrm{pg} / \mathrm{ml})$ e IL-17 (15.6 - $1000 \mathrm{pg} / \mathrm{ml})$.

Em síntese, placas de 96 poços NUNC-MAXISORP, foram sensibilizadas à temperatura ambiente durante a noite, com $100 \mu$ de anticorpos monoclonais especificos de captura para as citocinas: anti-IL-4, anti-IL-10, anti-IL-13 e anti-IL-17. As placas foram lavadas 3 vezes com

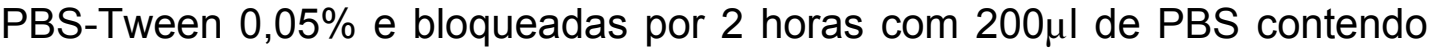
$1 \%$ de BSA e $5 \%$ de sacarose. Após este período as placas foram lavadas novamente, e $50 \mu \mathrm{l}$ das amostras ou da curva padrão foram adicionadas, seguindo incubação por 2 horas a temperatura ambiente. Após nova lavagem, foram adicionadas $100 \mu \mathrm{l}$ do anticorpo de detecção biotinilado específico para cada citocina: anti-IL-4, anti-IL-10, anti-IL-13 e anti-IL17 ,seguindo incubação por 2 horas a temperatura ambiente. As placas foram lavadas novamente e incubadas com solução de peroxidase de raiz forte conjugada (HRP) e avidina em PBS contendo 1\% de BSA, durante 20 minutos a $37^{\circ} \mathrm{C}$. Após a lavagem das placas, foram adicionadas $100 \mu \mathrm{l}$ do reagente para revelar a reação. Após 30 minutos, a reação foi interrompida com acido sulfúrico $1 \mathrm{M}$ e a densidade óptica lida a $450 \mathrm{~nm}$. A concentração das citocinas presentes nas amostras foi calculada com base nas curvas padrões. 


\section{Determinação da Espessura do Epitélio Nasal e Brônquico}

Nariz: A cabeça foi cuidadosamente separada do restante do corpo, dissecada a fim de, submete-la a fixação em solução de formalina tamponada a $4 \%$ por 24 horas, após este período a cavidade nasal foi imersa em solução de etilenodiaminotetracetato de tetrasódio (EDTA) a 5\% para descalcificação por 14 dias (Pires-Neto e cols, 2006). Ao término da descalcificação, a cavidade nasal foi dividida em três níveis de secção transversal: região 1 (proximal) o ponto de corte é imediatamente após o dente incisivo superior; região 2 (medial) com o ponto de corte próximo à papila incisiva, anteriormente ao palato duro; região 3 (distal) ponto de corte na metade do segundo dente molar (figura 1). Esta técnica, com este nível de corte, permite examinar melhor as células epiteliais na cavidade nasal (septo nasal) e interpretar a mudança após a intoxicação (Herbert and Leininger, 1999; Pires-Neto e cols, 2006).

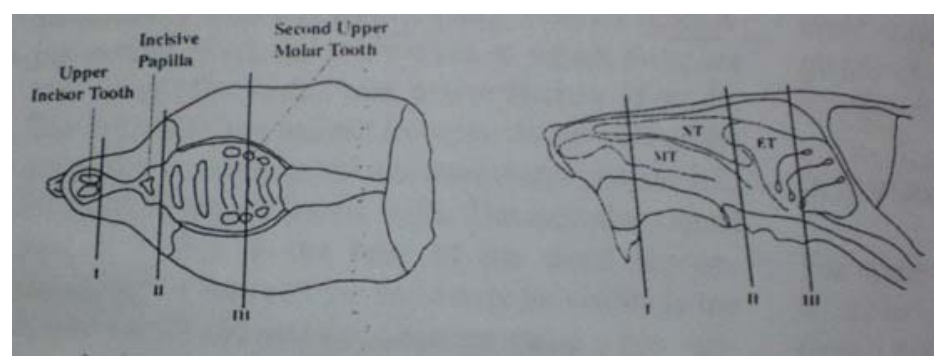

Figura 7: Ilustração da superfície ventral do crânio de camundongo evidenciando a estrutura utilizada para marcar o "ponto de corte" da cavidade nasal. A linha I, II e III indicam o nível do corte padronizado pelo Programa de Toxicologia Nacional - EUA (Hebert e Leininger,1999). 
As amostras foram embebidas em parafina e processadas de acordo com a rotina histológica. Cortes de $5 \mu \mathrm{m}$ de espessura foi obtida no nível proximal da cavidade nasal, imediatamente posterior ao dente incisivo superior. Lâminas foram preparadas e coradas com Ácido Periódico de Schiff e Azul Alciano (PAS/AB) com um pH de 2,5. Através desta técnica, as glicoproteínas neutras e ácidas são coradas em vermelha e azul respectivamente (Jones and Reid, 1978). O conteúdo do muco (ácido ou neutro) do epitélio respiratório da cavidade nasal foi quantificado por morfometria convencional. Usando um microscópio acoplado a uma câmera e a um sistema de análise de imagem. Nós digitalizamos a imagem microscópica a um vídeo de alta resolução e acoplamos uma grade de área conhecida (6.6564 $\mu \mathrm{m}^{2}$ de magnificação de $3300 \mathrm{X}$ ) contendo 884 quadrados e 3536 pontos no monitor. O número de pontos de cada tipo de muco e a área não secretora do epitélio foi contado em cada amostra, e o volume da proporção de muco neutro e ácido no epitélio respiratório foi determinado por contagem de pontos (Weibel, 1990, Pires-Neto et al, 2006). Nós calculamos o número de pontos correspondentes a área total do tecido epitelial de cada amostra. O cálculo utilizado para quantificar o conteúdo do muco foi o seguinte:

(pontos de interesse / pontos totais $\times 6.6564 \mu \mathrm{m}^{2}$ )

média da espessura $(\mu \mathrm{m}) \mathrm{X}$ comprimento da membrana basal $(\mu \mathrm{m})$ 
Para a determinação da espessura de epitélio do septo nasal foram analisados 10 campos (aumento 3300X).

Pulmões: Os pulmões após o lavado pulmonar foram colocados em formalina tamponada em pressão positiva de $20 \mathrm{cmH} 20$ durante 24 horas. Após, os pulmões foram cortados e encaminhados para procedimento histológico onde foram emblocados em parafina e cortados com $5 \mu \mathrm{m}$ de espessura. O tecido nas lâminas foi corado com Hematoxilina-Eosina (HE) Para cada animal, foram analisados cortes transversais de cinco bronquíolos, ou seja, aqueles com perfil de secção transversal adequada (menos de $10 \%$ da variação do diâmetro máximo e mínimo) foram utilizados para quantificação. O microscópio Leica DMR acoplado a uma câmera de vídeo colorida e um sistema de software de analise de imagem (Image Próplus), que digitaliza a imagem microscópica para o vídeo de alta resolução e um visor acoplado com área conhecida. A média da espessura do epitélio foi determinada através da medida entre o limite da membrana basal e ao limite de membrana apical (magnificação de 1380X). Cada valor obtido para cada uma das cinco vias aéreas foi em média, para fornecer um único ponto de dados para cada animal.

\section{Imunohistoquímica}

Para imunohistoquímica, cortes histológicos dos pulmões em lâminas silanizadas (3-Aminopropil-trietoxi-silano - Sigma) foram inicialmente desparafinizados e hidratados. E seguiu-se o protocolo abaixo descrito: 


\section{Hidratação e Bloqueio}

Após hidratação seguiu-se o bloqueio da peroxidade endógena com água oxigenada $\left(\mathrm{H}_{2} \mathrm{O}_{2}\right)$ 10V $3 \% 7$ vezes de 5 minutos cada, seguiu-se a lavagem com água e PBS.

\section{Recuperação antigênica}

Seguiu-se a recuperação antigênica com tampão citrato $(\mathrm{pH}=6)$ em temperatura alta. Após este período, as lâminas foram resfriadas por 20 minutos e lavadas em PBS.

\section{Incubação com o anticorpo primário}

Após os bloqueios, seguiu-se a incubação com os anticorpos primários: anti-IL-13 (sc1778, Santa Cruz) diluído em BSA na proporção de 1:60 (IL-13), os quais foram aplicados sobre os cortes relativos ao experimento e controles (positivo e negativo) de tecido, e as lâminas incubadas durante a noite.

As lâminas então foram lavadas em PBS e incubadas anticorpo secundário que contém o sistema HRP (DakoCytomation K0690). Após esta etapa, as lâminas foram lavadas em PBS e seguiu-se a revelação pelo cromógeno 3,3 Diaminobenzidine (DAB) (Sigma Chemical Co, St Louis, MO, $E U A)$. As lâminas foram lavadas abundantemente em água corrente $\mathrm{e}$ contra-coradas com Hematoxilina de Harris (Merck, Darmstadt, Alemanha). Em seguida, as mesmas foram lavadas em água corrente, desidratadas, diafanizadas e montadas com resina para microscopia Entellan (Merck, Darmstadt, Alemanha). 


\section{Quantificação da expressão de mediadores inflamatórios no} tecido epitelial (Porcentagem de inflamação peribrônquica para IL-13)

Foram analisadas cinco vias aéreas de cada animal, três a cinco campos por via aérea, avaliados num aumento de 400X. A área para a avaliação da expressão de IL-13 do epitélio foi calculada a partir da área positiva dividida pela área total analisada no epitélio. Os resultados foram expressos na relação de área positiva para IL-13 sobre área total analisada.

\section{EXTRAÇÃO DE RNA TOTAL}

O RNA total foi extraído utilizando o reagente TRIzo $^{\circledR}$ (Invitrogen Life Technologies) conforme $\mathrm{o}$ protocolo do fabricante modificado por Chomczynski e Sacchi (1987). Após a remoção cirúrgica, os pulmões de cada animal foram individualmente lavados e embebidos em $2 \mathrm{ml}$ de trizol. Cada amostra foi rapidamente homogeneizada em politron (Kinematic), transferidas para tubos eppendorf onde ficaram homogeneizando durante 5 minutos a temperatura ambiente para permitir a completa dissociação dos complexos de nucleoproteínas. Em seguida, foram adicionados $200 \mu \mathrm{L}$ de clorofórmio (Merck) e os tubos foram homogeneizados por inversão e deixados à temperatura ambiente por 2 minutos seguido de uma centrifugação de 15 minutos a $12.000 \times$ a a $4^{\circ} \mathrm{C}$. Este procedimento resultou em 3 fases: a fase aquosa onde está o RNA, a interface que contém proteínas e DNA e por fim a fase com o fenol/clorofórmio. Após a transferência da fase aquosa para um novo tubo, foram adicionados $500 \mu \mathrm{L}$ 
de álcool isopropílico (Merck) para a precipitação do RNA e este foi incubado por 1 hora à temperatura ambiente. A seguir os tubos foram centrifugados a $12000 x g$ por 10 minutos a $4^{\circ} \mathrm{C}$. O RNA precipitado foi então lavado com etanol $75 \%$ (Merck) e centrifugado a $7500 \times$ g por 5 minutos a $4^{\circ} \mathrm{C}$. As amostras foram dissolvidas em água DEPC (água tratada com o inibidor de RNAse, dietilpirocarbonato - Merck) e incubadas por 10 minutos a $60^{\circ} \mathrm{C}$ para completa dissolução do RNA.

A concentração de RNA foi determinada por espectrofotometria em comprimento de onda 260 e $280 \mathrm{~nm}$, onde comprimento em $260 \mathrm{~nm}$ refere-se à quantidade de ácido nucléico (OD de 1 representa $40 \mu \mathrm{g} / \mathrm{ml}$ de RNA) e o 280nm refere-se à quantidade de proteína. A relação entre as absorbâncias nos comprimentos de ondas $260 / 280 \mathrm{~nm}$ foi considerada de boa qualidade quando dentro dos valores 1,70 a 2,0. A integridade do material foi verificada em gel de agarose (Promega). Para isso utilizamos $0,8 \%$ de agarose em MOPS 1x (2M MOPS, 0,5M de Acetato de Sódio e 0,1M de EDTA pH 7,0) e 5\% de Formaldeído. Aproximadamente $0,5 \mu \mathrm{g}$ de RNA extraído foram preparados em tampão para RNA (53\% de Formaminda, 6\% Formaldeído, 7\% Glicerol, 6\% Azul de Bromofenol e 10\% de MOPS 10x) e Brometo de etídio. As amostras foram incubadas em banho-maria a $65^{\circ} \mathrm{C}$ por 15 minutos, em seguida colocadas no gelo por 2 minutos e aplicadas no gel. A corrida de eletroforese foi realizada em tampão MOPS 1x com uma voltagem constante de 60 volts em temperatura ambiente até que as amostras estivessem com as bandas correspondentes aos RNA ribossomais $28 \mathrm{~S}$ e $18 \mathrm{~S}$ bem separadas. Consideramos a qualidade satisfatória quando a 
banda $28 \mathrm{~S}$ se mostrou duas vezes mais intensa que a banda $18 \mathrm{~S}$ e ausência de arraste.

\section{TRANSCRIÇÃO REVERSA (RT)}

Para a síntese do cDNA, foram utilizados aproximadamente $10 \mu \mathrm{g}$ de RNA total, aos quais acrescentaram-se $2 \mu \mathrm{L}$ de Oligo dT $500 \mu \mathrm{g} / \mathrm{mL}$ (Invitrogen), $2 \mu \mathrm{L}$ de dNTP mix $10 \mathrm{mM}$ (Invitrogen), $2 \mu \mathrm{L}$ de água DEPC. A mistura foi aquecida a $65^{\circ} \mathrm{C}$ por 5 minutos e rapidamente esfriada em gelo. Após uma breve centrifugação, adicionou-se $8 \mu \mathrm{L}$ de tampão $5 x$ first-strand (Invitrogen), $2 \mu \mathrm{L}$ de DTT $0,1 \mathrm{M}$ e $2 \mu \mathrm{L}$ de RNaseOUT (Recombinant RNase Inhibitor, Invitrogen). Essa solução foi cuidadosamente homogeneizada e 2 $\mu \mathrm{L}$ da enzima Superscript III RT (200 U/ $\mu \mathrm{L}$ ) foram adicionados seguida da incubação por 50 minutos a $50^{\circ} \mathrm{C}$. A reação foi inativada a $70^{\circ} \mathrm{C}$ por 15 minutos e armazenado no freezer a $-20^{\circ} \mathrm{C}$ até o momento do uso.

\section{PCR em tempo real}

Este método foi utilizado para determinar a expressão do gene MUC5AC com a utilização do fluoróforo SYBR ${ }^{\circledR}$ Green. Essa metodologia baseia-se na intercalação do $S Y B R^{\circledR}$ Green na dupla fita de DNA e no monitoramento da fluorescência emitida em cada ciclo da amplificação. Porém, o fluoróforo pode ligar-se a qualquer dupla fita formada durante a reação incluindo dímeros de oligonucleotídeos (Ririe et al., 1997). Portanto, 
a especificidade da reação é verificada através de uma curva de desnaturação que eleva a temperatura até que ocorra a desnaturação completa do produto da PCR, onde um único pico de fluorescência é indicativo de uma reação específica.

Nas reações foram utilizados $20 \mathrm{mM}$ de Tris- $\mathrm{HCl}(\mathrm{pH} 8,4), 50 \mathrm{mM}$ de

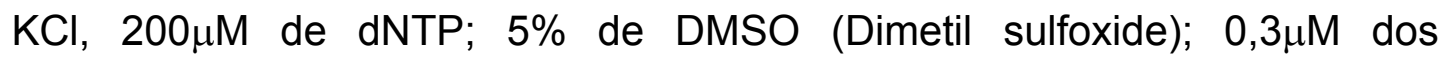
oligonucleotídeos senso e anti-senso para MUC5AC e $\beta$-actina (Tabela X); 1,5mM de $\mathrm{MgCl}_{2} ; 1,5 \mathrm{x}$ de SYBR Green; $1,5 \mathrm{U}$ de Platinum ${ }^{\circledR}$ Taq DNA Polymerase (Invitrogen) e $100 \eta$ g do cDNA em um volume final de $20 \mu \mathrm{l}$. As amostras foram amplificadas com uma desnaturação inicial de $95^{\circ} \mathrm{C}$ por 5 minutos, 40 ciclos de desnaturação a $95^{\circ} \mathrm{C}$ por 15 segundos, hibridização a $58^{\circ} \mathrm{C}$ por um minuto, extensão a $72^{\circ} \mathrm{C}$ por um minuto. A curva de desnaturação foi realizada variando a temperatura no intervalo de $72^{\circ} \mathrm{C}$ a $99^{\circ} \mathrm{C}$, sendo $1^{\circ} \mathrm{C}$ por etapa.

Tabela 3: Oligonucleotídeos usados no ensaio de PCR em tempo real (Lankford et al., 2005)

\begin{tabular}{|c|c|c|c|}
\hline \multicolumn{2}{|c|}{ Oligonucleotídeos } & \multirow{2}{*}{$\begin{array}{c}\text { Sequência } \\
\text { 5'-ACGACACTTTTCAGTACCAATGAC -3' } \\
\text { 5'-GCTTCCTTACAGATGCAGTCCT -3' }\end{array}$} & \multirow{2}{*}{$\begin{array}{l}\text { Tamanho do } \\
\text { produto }\end{array}$} \\
\hline MUC5AC & $\begin{array}{c}\text { Senso } \\
\text { Anti-senso }\end{array}$ & & \\
\hline$\beta$-actina & $\begin{array}{l}\text { Senso } \\
\text { Anti-senso }\end{array}$ & $\begin{array}{l}\text { 5'-CTGTGGCATCCACGAAACTA -3' } \\
\text { 5'- AGTACTTGCGCTCAGGAGGA-3' }\end{array}$ & $200 \mathrm{pb}$ \\
\hline
\end{tabular}

A expressão de cada RNAm foi normalizada em relação a expressão do gene da $\beta$-actina. Os ensaios foram realizados em duplicata e foi aceito uma variação entre a duplicata menor que 1,0 no seu $C_{t}$ (ciclo do Threshold), de acordo com as instruções do fabricante do aparelho Rotor-Gene RG3000 
(Corbett Research). Além disso, em todos os ensaios havia uma mesma amostra chamada de referência e um controle negativo no qual não continha cDNA.

O resultado da PCR em tempo real foi analisado com auxilio do programa Rotor-Gene 6 versão 6.0 (Corbett Research). Os resultados obtidos foram normalizados através do modelo matemático proposto por PFAFFL (2001).

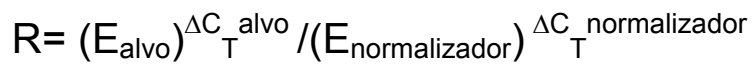

Onde $E_{\text {alvo }}$ corresponde à eficiência da amplificação dos oligonucleotídeos para o gene alvo e $E_{\text {normalizador }}$ corresponde à eficiência da amplificação dos oligonucleotídeos para o gene normalizador ( $\beta$-actina). As eficiências foram calculadas como $10^{(-1 / \text { slope })}$, sendo que o slope corresponde à inclinação da reta obtida quando se analisa a variação do $\mathrm{C}_{\mathrm{T}}$ em função do $\log$ de diferentes quantidades de cDNA e uma eficiência de $100 \%$ da reação de equivale a 2. $\mathrm{O} \Delta \mathrm{C}_{\text {Talvo }}$ é a média do $\mathrm{C}_{\mathrm{T}}$ do gene alvo na amostra referência subtraída da média do $\mathrm{C}_{\mathrm{T}}$ da amostra alvo. $\mathrm{O} \Delta \mathrm{C}_{\text {Tnormalizador }}$ por sua vez, é a média do $\mathrm{C}_{\mathrm{T}}$ do gene normalizador na amostra referência subtraída da média do $\mathrm{C}_{\mathrm{T}}$ da amostra normalizadora.

\section{Análise estatística}

Os dados foram analisados através do software SigmaStat 9.0 (Califórnia, EUA). O teste Mann-Whitney Rank Sum foi utilizado para todos os dados do experimento (Sigmastat 9.0). O nível de significância considerado é $p<0,05$. 
RESULTADOS 


\title{
RESULTADOS
}

\begin{abstract}
A seguir apresentamos dados do grupo que recebeu instilação intranasal durante o período de exposição de 30 e 60 dias com concentração de $15 \mu \mathrm{g} / 10 \mu \mathrm{l}$ e $30 \mu \mathrm{g} / 10 \mu \mathrm{l}$ de DEP.
\end{abstract}

Na figura 8 observa-se um exemplo do epitélio respiratório que reveste o trato respiratório proximal (septo da cavidade nasal) nos animais dos grupos Controle e expostos ao DEP de concentrações $15 \mu \mathrm{g} / 10 \mu \mathrm{l}$ de salina e 30 $\mathrm{g} / 10 \mu \mathrm{l}$ de salina, no período de exposição 30 e 60 dias. 


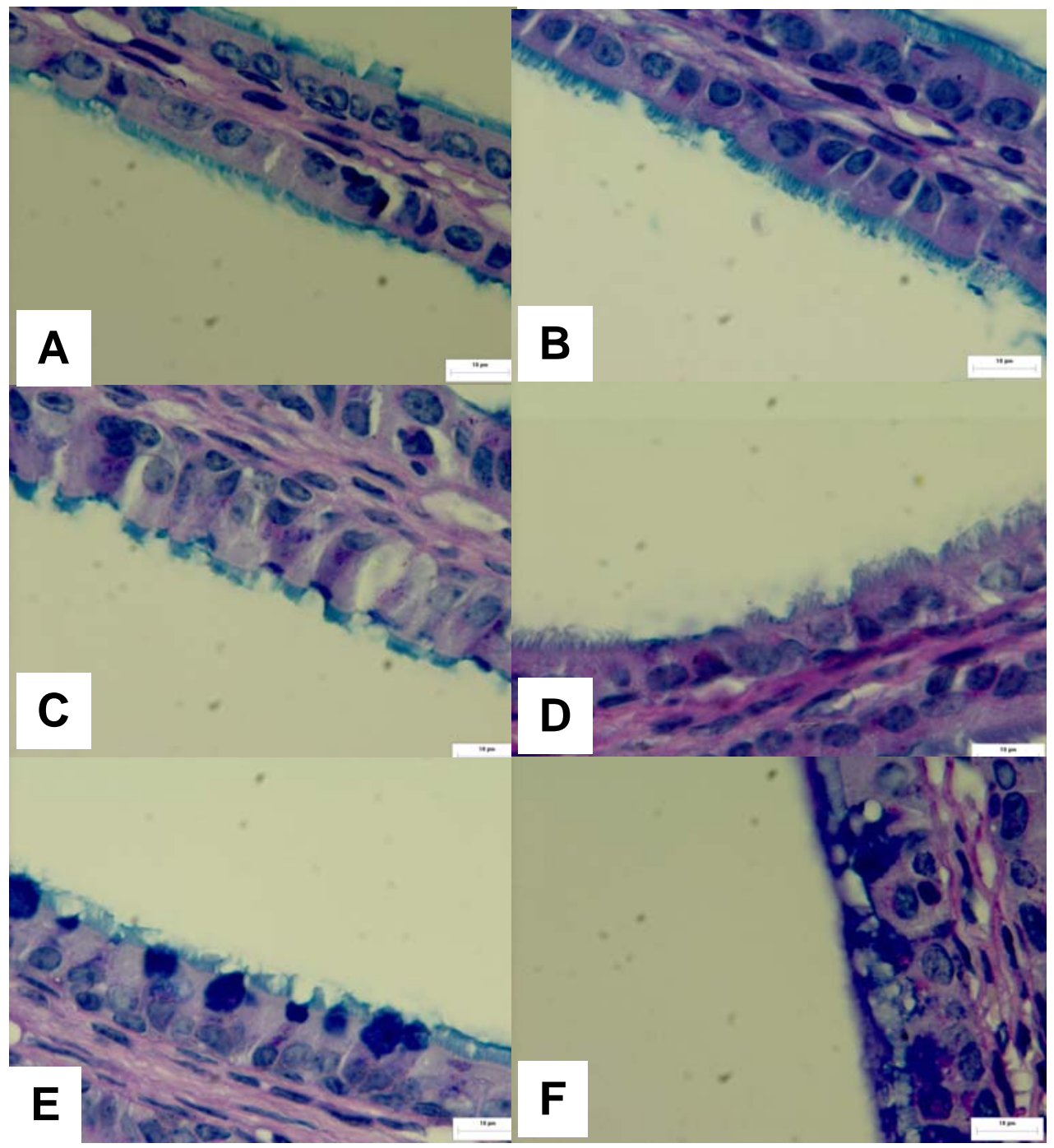

Figura 8: O epitélio respiratório que reveste o septo da cavidade nasal é do tipo pseudo-estratificado colunar ciliado com células caliciformes que são secretoras de muco. No grupo Controle 30 dias (A), grupo Controle 60 dias (B) observam-se as células colunares com uma grande quantidade de cílios. E no grupo exposto ao DEP de concentrações $15 \mu \mathrm{g} / 10 \mu$ de salina 30 dias

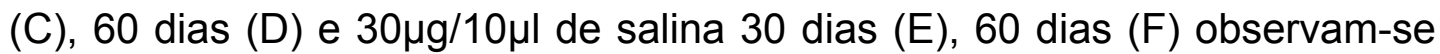
uma grande quantidade de muco intraepitelial (PAS/AB 1000x). 
O gráfico 1 apresenta os resultados da analise da espessura de epitélio do septo nasal para todos os grupos e tempos de exposição de 30 e 60 dias de exposição. A exposição ao DEP induz um aumento da espessura

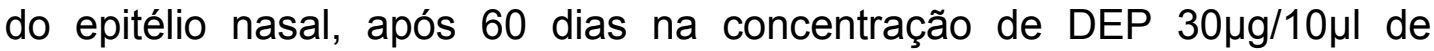
solução salina quando comparado com o grupo Controle $(p=0,042)$. Após 30 dias de exposição não houve diferença significante entre os grupos.

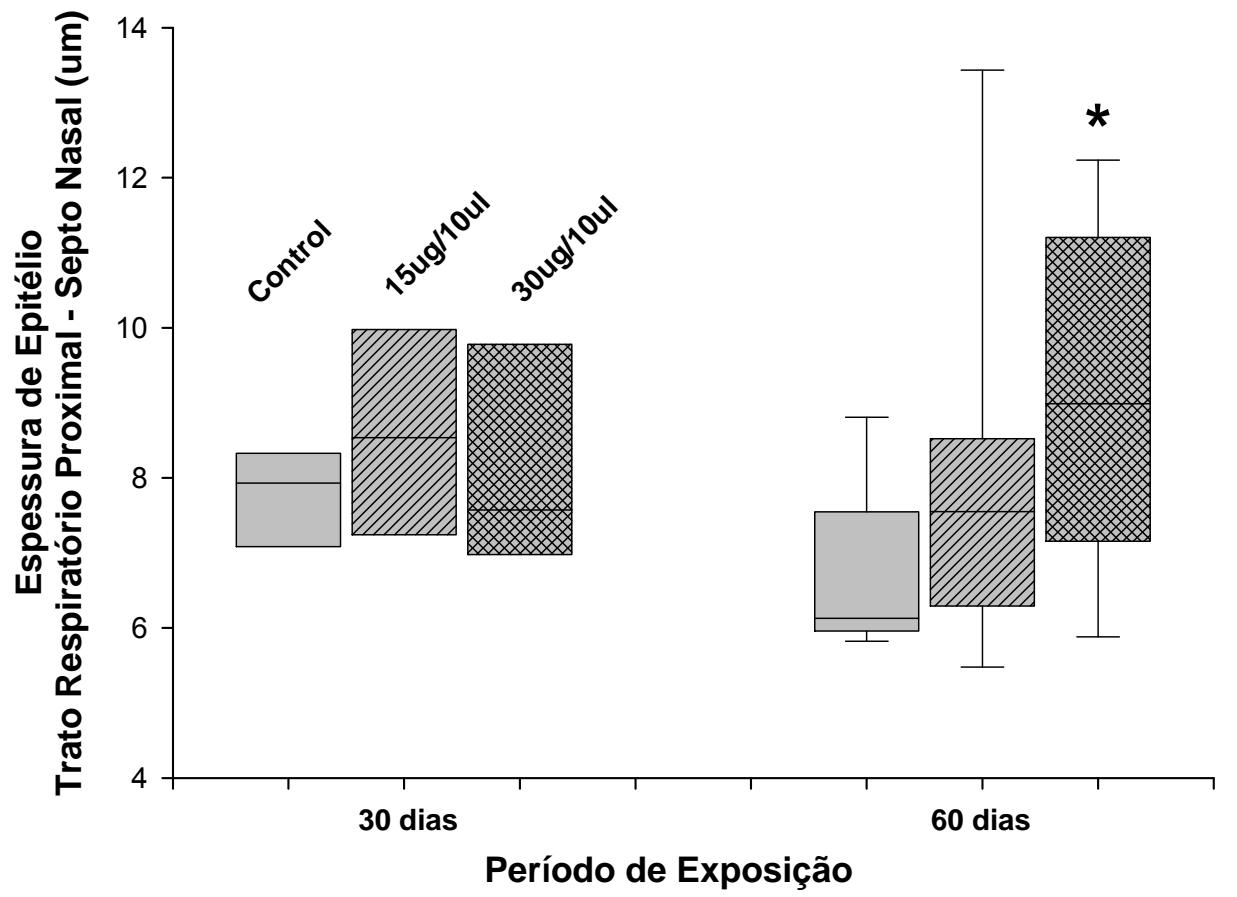

Gráfico 1: Representação gráfica dos efeitos do DEP sobre a espessura da camada epitelial das vias aéreas proximais (septo nasal) em $\mu \mathrm{g}$. Grupo Controle e grupo exposto ao DEP nas concentrações de $15 \mu \mathrm{g} / 10 \mu \mathrm{l}$ e $30 \mu \mathrm{g} / 10 \mu \mathrm{l}$ de solução salina, nos períodos de exposição de 30 e 60 dias. Valores expressos em "boxplot" (a linha media define a mediana, as bordas acima e abaixo do retângulo representam os percentis 25 e $75 \%$ respectivamente, e as linhas terminais da barra de erro (abaixo e acima) representam os percentis 10 e $90 \%$, respectivamente). O grupo dos animais 
expostos a $30 \mu \mathrm{g} / 10 \mu \mathrm{l}$ de salina em 60 dias de exposição mostrou uma diferença estatisticamente significante em relação aos grupos Controle. ${ }^{*} p=0,042$.

$\mathrm{Na}$ análise da porcentagem de área epitelial ocupada por muco ácido no epitélio nasal, os grupos que receberam DEP, nas concentrações de $15 \mu \mathrm{g} / 10 \mu \mathrm{l}$ e $30 \mu \mathrm{g} / 10 \mu \mathrm{l}$ não foram diferentes em relação ao grupo controle entre os períodos de 30 e 60 dias de exposição. Após 30 dias de instilação nasal não houve diferença entre os grupos. Após 60 dias de instilação nasal aumentou o conteúdo de muco acido na área epitelial com DEP $30 \mu \mathrm{g} / 10 \mu \mathrm{l}$ em relação ao grupo Controle $(p=0,017)$.

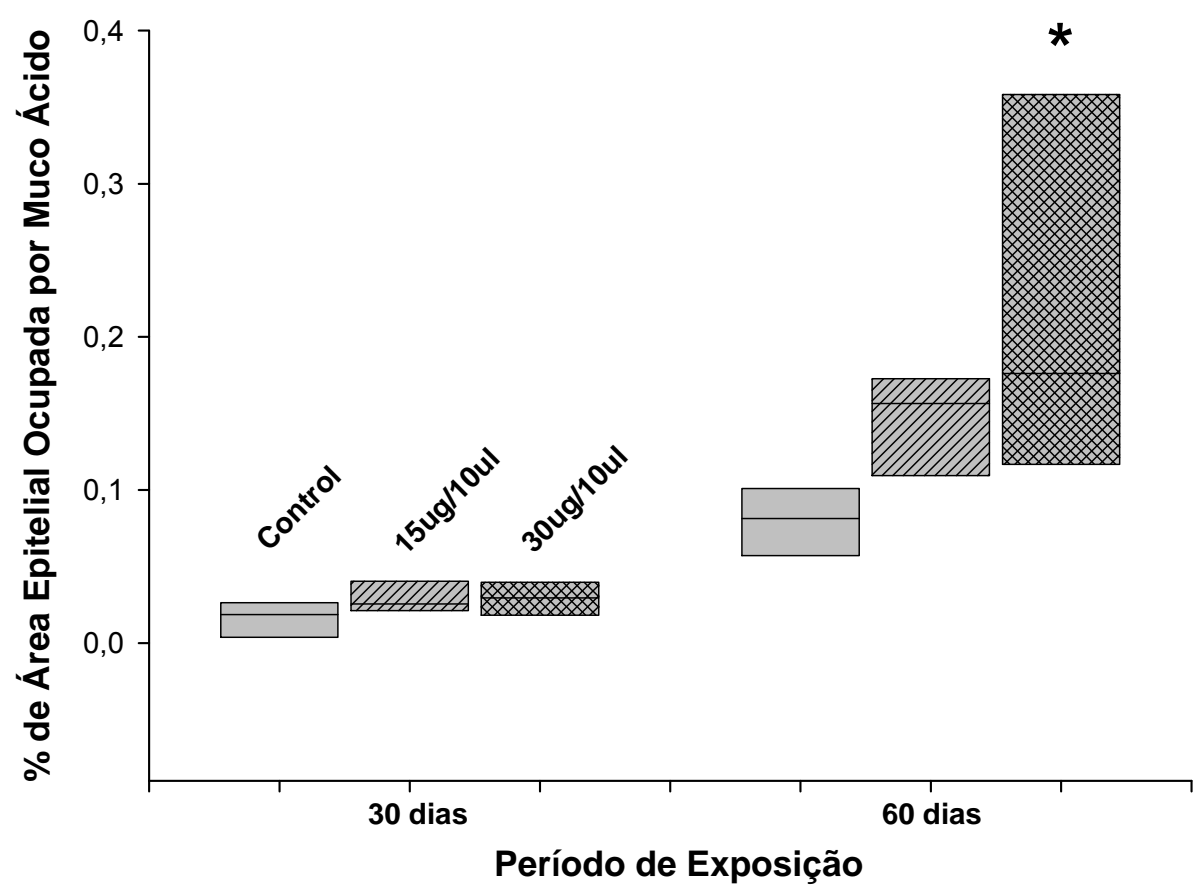

Gráfico 2: Efeito do DEP de concentrações $15 \mu \mathrm{g} / 10 \mu \mathrm{l}$ e $30 \mu \mathrm{g} / 10 \mu \mathrm{l}$ de salina e grupo Controle sobre a porcentagem de área epitelial ocupada por muco ácido no septo nasal. Valores expressos em box plot (detalhes descritos no

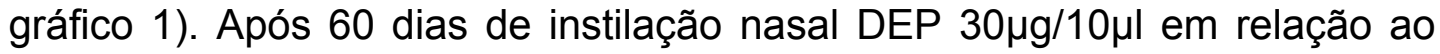


grupo Controle mostrou diferença significante para o conteúdo de muco ácido ocupado na área epitelial do septo nasal * $p=0,017$.

Os grupos que receberam DEP, nas concentrações de $15 \mu \mathrm{g} / 10 \mu \mathrm{l}$ e

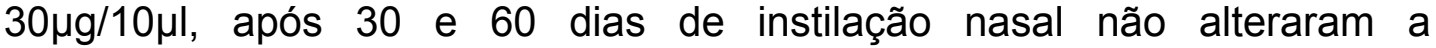
porcentagem de área epitelial ocupada por muco neutro.

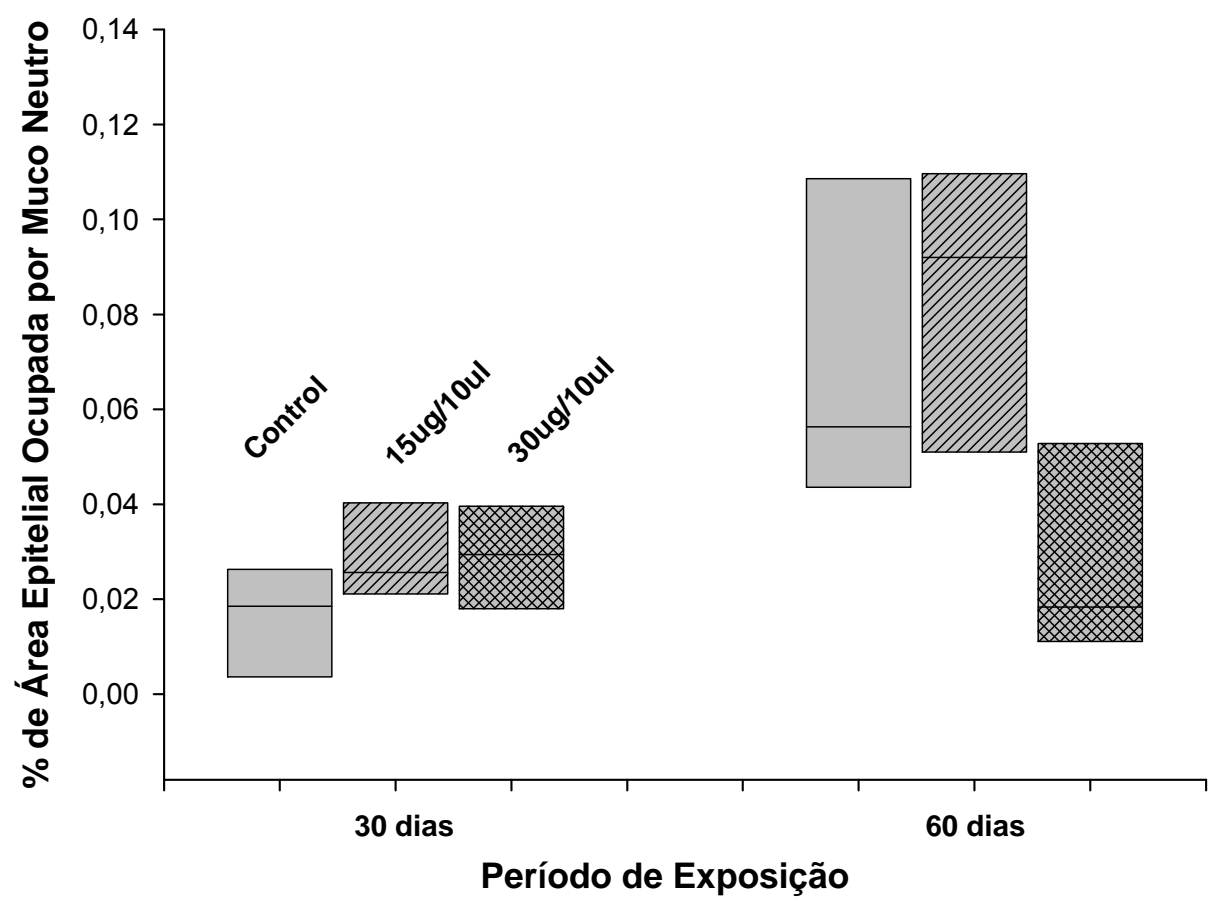

Gráfico 3: Efeito do DEP de concentrações $15 \mu \mathrm{g} / 10 \mu \mathrm{l}$ e $30 \mu \mathrm{g} / 10 \mu \mathrm{l}$ de salina e grupo Controle sobre a porcentagem de área epitelial ocupada por muco neutro no septo nasal. Valores expressos em box plot (detalhes descritos no gráfico 1). Não houve diferença estatística quando instilado $15 \mu \mathrm{g} / 10 \mu \mathrm{l}$ e $30 \mu \mathrm{g} / 10 \mu \mathrm{l}$ de solução salina, após 30 e 60 dias. 
A inflamação pulmonar foi avaliada através da quantificação de células totais e diferenciais no lavado broncoalveolar (LBA). O gráfico abaixo representa o número de células inflamatórias totais encontradas nos animais que receberam o DEP nas concentrações de $15 \mu \mathrm{g} / 10 \mu \mathrm{l}$ de salina, $30 \mu \mathrm{g} / 10 \mu \mathrm{l}$ de solução salina ou somente solução salina (grupo Controle) no período de 30 e 60dias. Os animais que receberam $30 \mu \mathrm{g} / 10 \mu \mathrm{l}$ de solução salina nos períodos de 30 dias $(p=0,033)$ e 60 dias $(p<0,001)$, em relação ao grupo Controle, tiveram um aumento no número total de células inflamatórias totais no LBA.

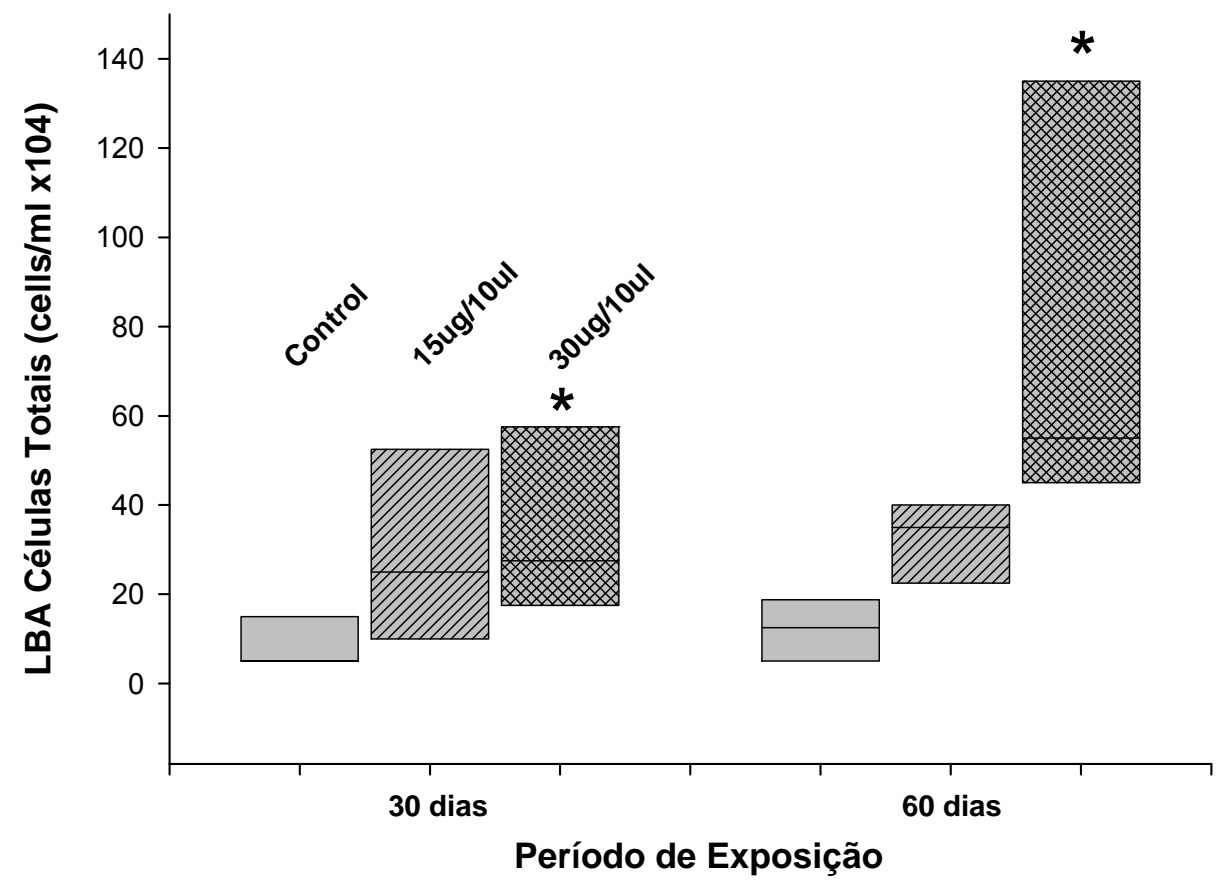

Gráfico 4: Efeito do DEP nas concentrações $15 \mu \mathrm{g} / 10 \mu \mathrm{l}$ de solução salina e $30 \mu \mathrm{g} / 10 \mu \mathrm{l}$ de solução salina e o grupo Controle sobre o número total de células inflamatórias no lavado broncoalveolar (LBA). Valores expressos em box plot (detalhes descritos no gráfico 1). O grupo de animais que receberam instilação nasal de $30 \mu \mathrm{g} / 10 \mu \mathrm{l}$ de solução salina em 30 e 60 dias de exposição mostrou uma diferença estatisticamente significante em 
relação ao grupo Controle. ${ }^{*} p=0,033 ;{ }^{* *} p<0,001$ quando comparado com o grupo Controle.

O gráfico abaixo apresenta o número de macrófagos no LBA entre os grupos que receberam concentrações de DEP de $15 \mu \mathrm{g} / 10 \mu \mathrm{l}$ de salina e $30 \mu \mathrm{g} / 10 \mu \mathrm{l}$ de salina ou somente solução salina (grupo Controle) no período de 30 e 60 dias. Neste gráfico evidencia-se o aumento de macrófagos após o período de 60 dias, de instilação nasal de DEP na concentração de $30 \mu \mathrm{g} / 10 \mu \mathrm{l}$ de solução salina. No período de 30 dias não houve diferença significativa entre os grupos.

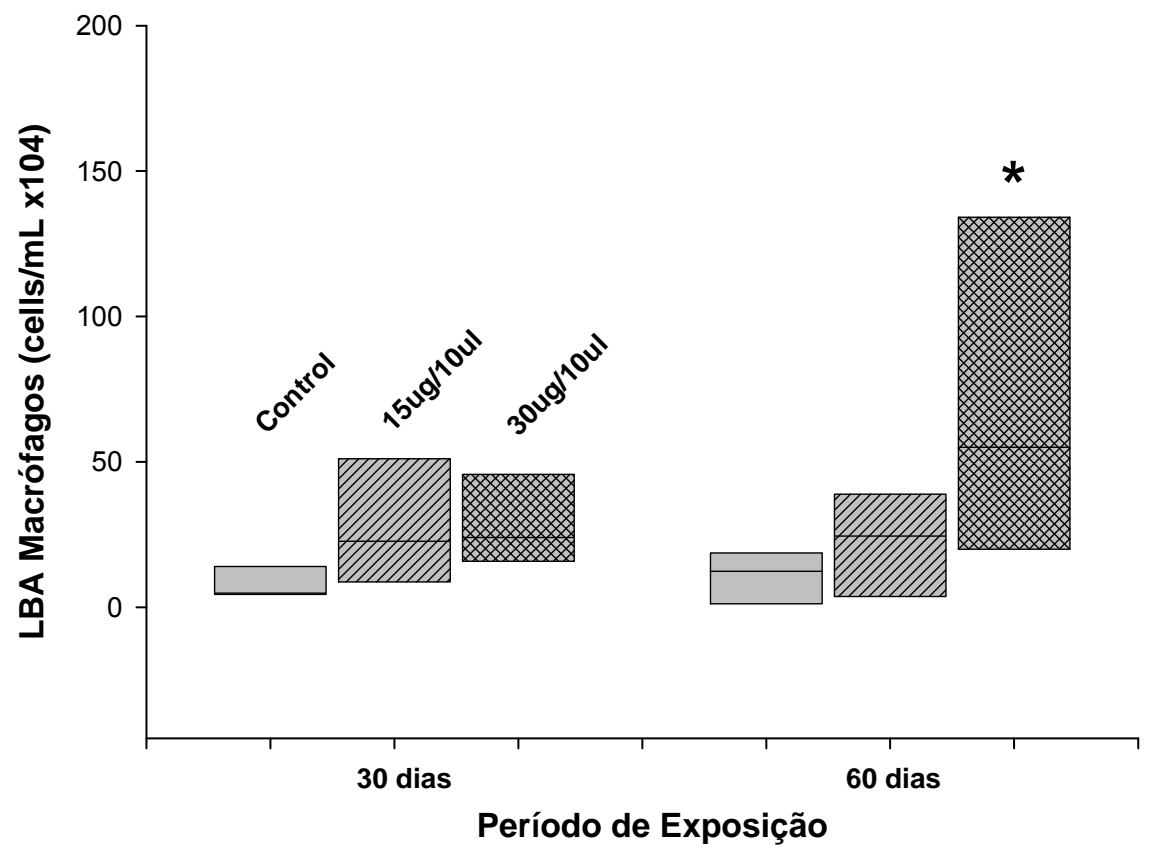

Gráfico 5: Representação gráfica do efeito do DEP nas concentrações $15 \mu \mathrm{g} / 10 \mu \mathrm{l}$ e $30 \mu \mathrm{g} / 10 \mu \mathrm{l}$ de salina e grupo Controle sobre o número de macrófagos encontrados no lavado broncoalveolar (LBA) nos períodos de 30 e 60 dias. Valores estão expressos em "boxplot" (detalhes descritos no gráfico 1). O grupo dos animais expostos a $30 \mu \mathrm{g} / 10 \mu \mathrm{l}$ de solução salina em 
60 dias de exposição mostrou uma diferença estatisticamente significante em relação ao grupo Controle. * $p=0,035$.

O gráfico abaixo apresenta a representação do número de linfócitos no LBA nos grupos $15 \mu \mathrm{g} / 10 \mu \mathrm{l}, 30 \mu \mathrm{g} / 10 \mu \mathrm{l}$ de salina e grupo controle nos períodos de 30 e 60 dias. Os grupos que receberam concentrações de DEP de $15 \mu \mathrm{g} / 10 \mu \mathrm{l}$ e $30 \mu \mathrm{g} / 10 \mu \mathrm{l}$ no período de 30 dias tiveram um aumento quando comparados com o gripo Controle $(p=0,002)$. Este aumento não foi observado quando os animais receberam DEP no período de 60 dias.

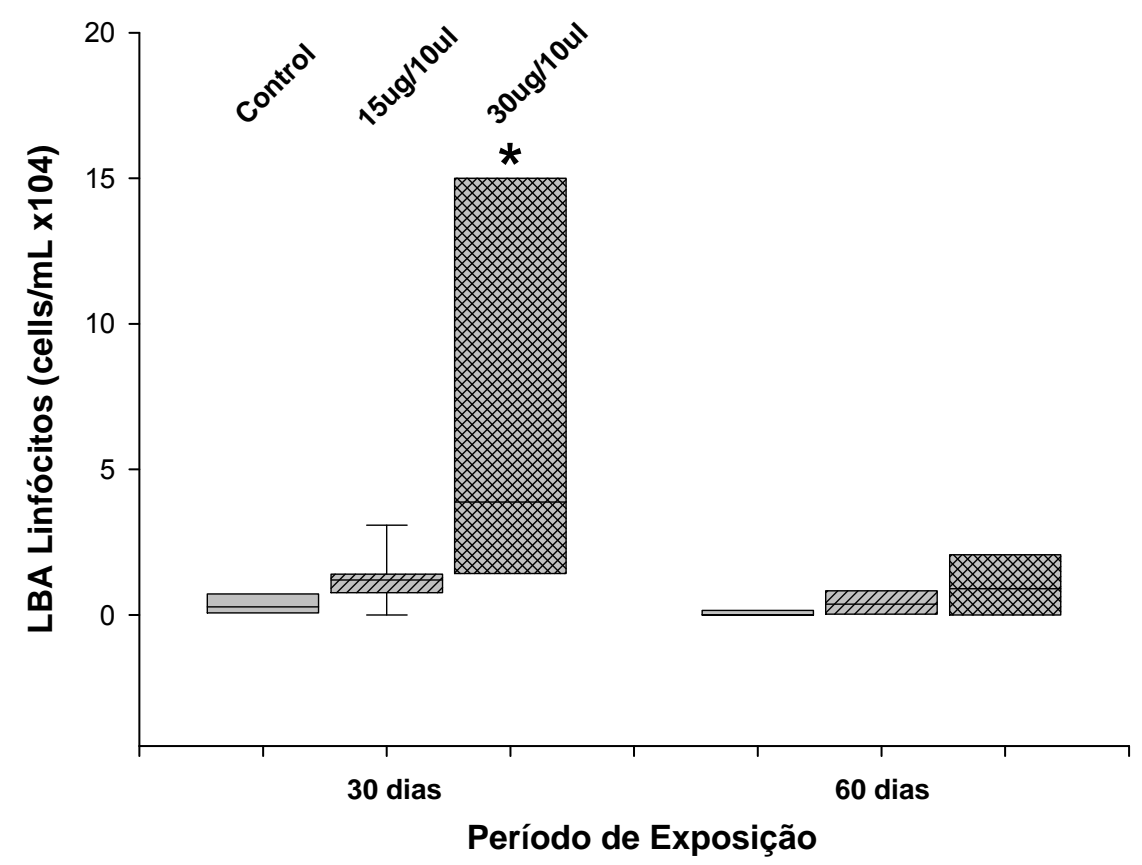

Gráfico 6: Efeito do DEP nas concentrações $15 \mu \mathrm{g} / 10 \mu \mathrm{l}$ e $30 \mu \mathrm{g} / 10 \mu \mathrm{l}$ de solução salina e grupo Controle sobre o número de linfócitos no lavado broncoalveolar (LBA). Valores expressos em boxplot (detalhes descritos no gráfico 1). O grupo dos animais expostos a $30 \mu \mathrm{g} / 10 \mu \mathrm{l}$ de solução salina em 
30 dias de exposição mostrou uma diferença estatisticamente significante em relação ao grupo Controle. * $p=0,002$.

O gráfico abaixo apresenta a representação do número de neutrófilos no LBA nos grupos $15 \mu \mathrm{g} / 10 \mu \mathrm{l}, 30 \mu \mathrm{g} / 10 \mu \mathrm{l}$ de salina e grupo controle nos períodos de 30 e 60 dias. Os grupos que receberam concentrações de DEP de $15 \mu \mathrm{g} / 10 \mu \mathrm{l}$ e $30 \mu \mathrm{g} / 10 \mu \mathrm{l}$ no período de 30 e 60 dias, não foi observado diferença estatística entre os grupos.

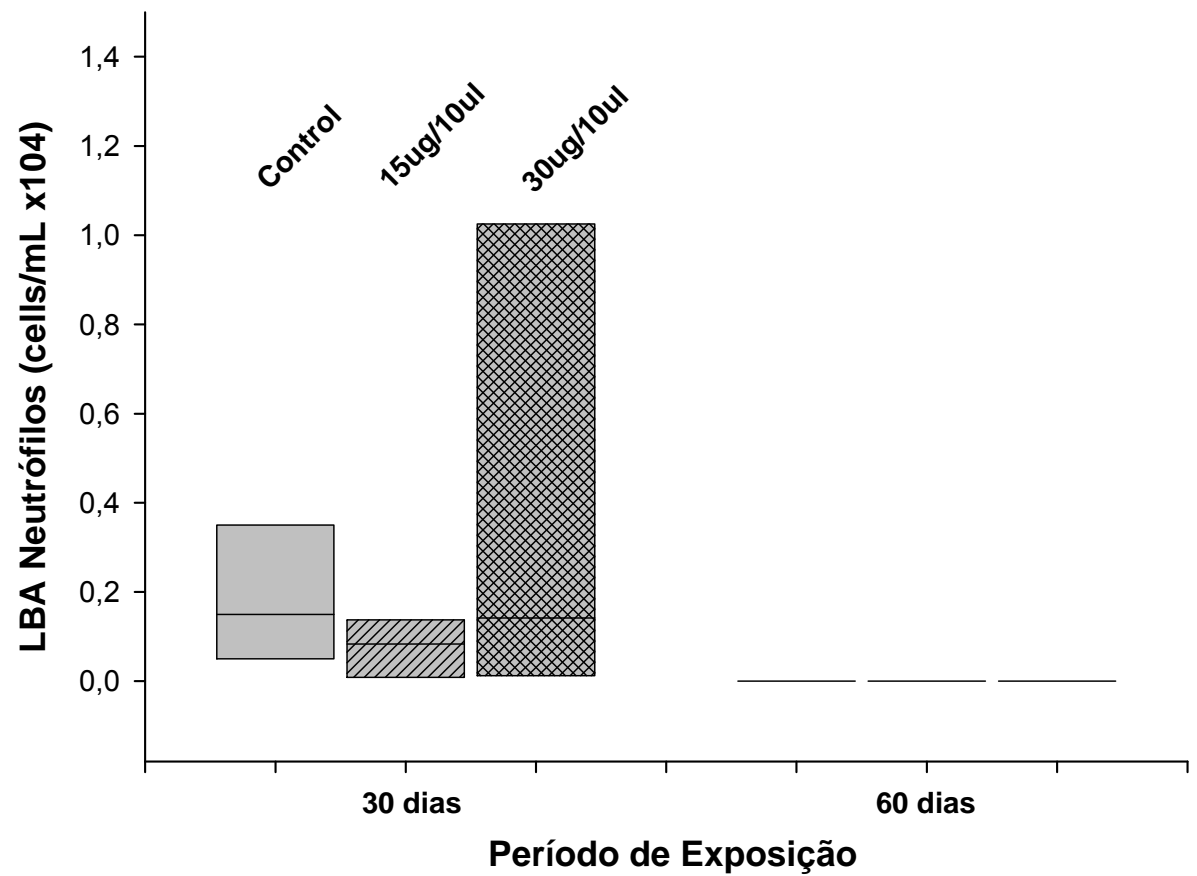

Gráfico 7: Efeito do DEP nas concentrações $15 \mu \mathrm{g} / 10 \mu \mathrm{l}$ e $30 \mu \mathrm{g} / 10 \mu \mathrm{l}$ de salina e grupo Controle sobre o número de neutrófilos no lavado broncoalveolar (LBA). Valores expressos em boxplot (detalhes descritos no gráfico 1). O grupo dos animais expostos a $15 \mu \mathrm{g} / 10 \mu \mathrm{l}$ e $30 \mu \mathrm{g} / 10 \mu \mathrm{l}$ de salina em 30 e 60 dias de exposição não mostrou diferença estatisticamente significante em relação aos grupos. 
Não foram observadas diferenças no número de eosinófilos no LBA quando comparado entre todos os grupos.

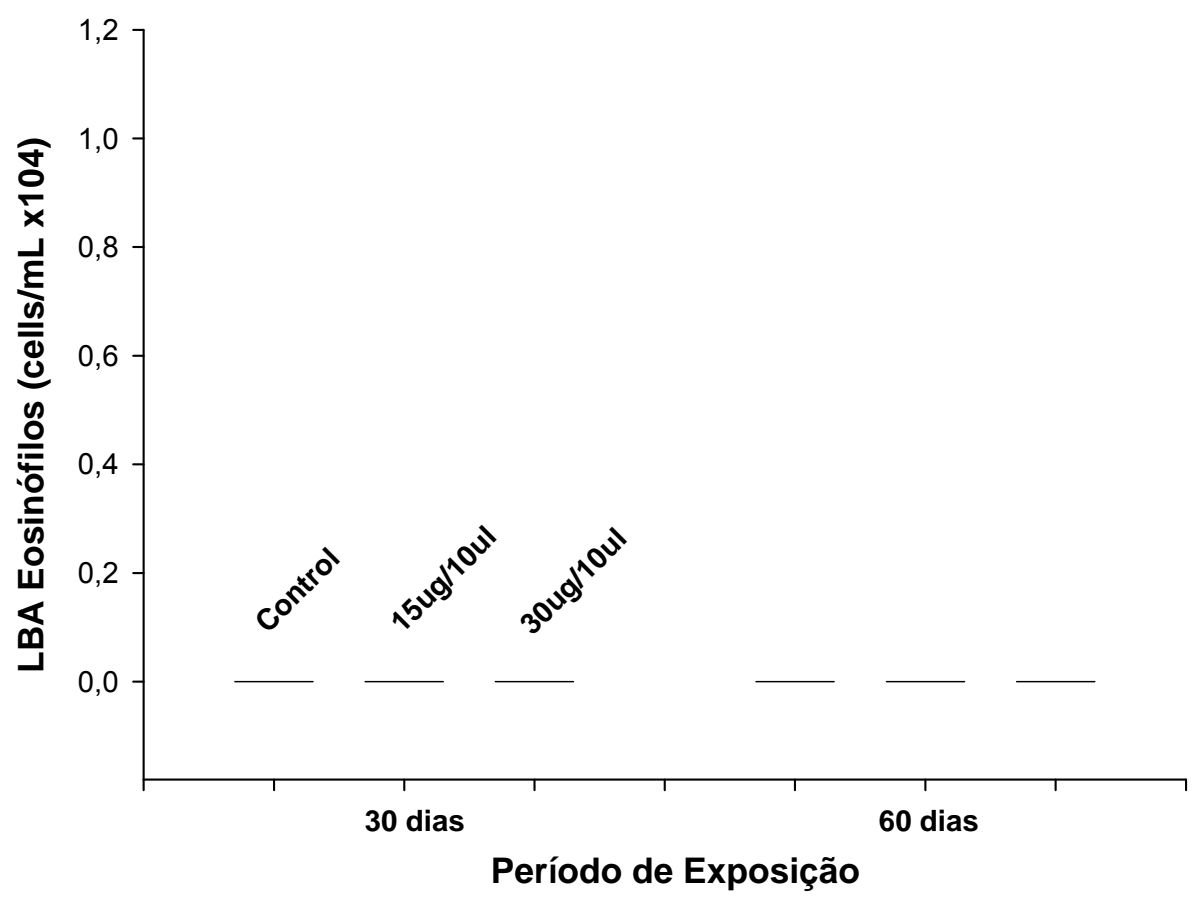

Gráfico 8: Efeito do DEP nas concentrações $15 \mu \mathrm{g} / 10 \mu \mathrm{l}$ e $30 \mu \mathrm{g} / 10 \mu \mathrm{l}$ de salina e grupo controle sobre o número de eosinófilos no lavado broncoalveolar (LBA). Valores expressos em boxplot (detalhes descritos no gráfico 1). Sem diferença estatística quando comparado com todos os demais grupos. 
Foram feitas determinações do nível de interleucinas IL-13, IL-4, IL-10 e IL-17 no LBA. No gráfico 6 a instilação de DEP não alterou o nível de IL13, após 30 e 60 dias recebendo doses de concentraçoes de DEP $15 \mu \mathrm{g} / 10 \mu \mathrm{l}$ e $30 \mu g / 10 \mu l$ de solução salina.

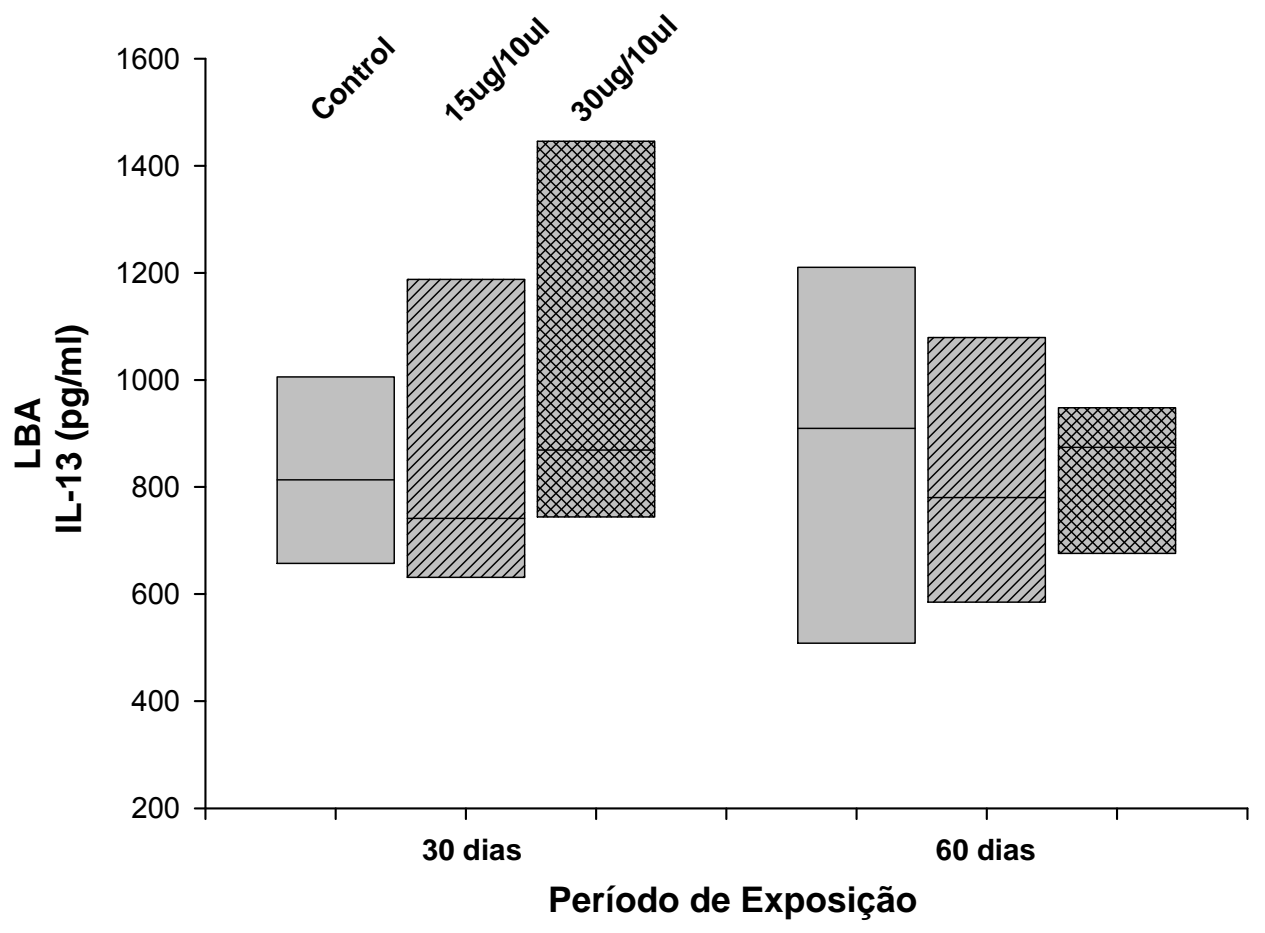

Gráfico 9: Efeito do DEP de concentrações $15 \mu \mathrm{g} / 10 \mu \mathrm{l}$ e $30 \mu \mathrm{g} / 10 \mu \mathrm{l}$ de salina e grupo controle sobre células inflamatórias positivas para IL- 13. Valores expressos em box plot (detalhes descritos no gráfico 1). O grupo dos animais expostos a DEP $15 \mu \mathrm{g} / 10 \mu \mathrm{l}$ e $30 \mu \mathrm{g} / 10 \mu \mathrm{l}$ de salina não houve diferença estatística entre os grupos. 
O DEP não alterou o nível de células inflamatórias positivas para IL- 4 e IL-10 quando comparado com o grupo Controle.

Com relação a IL-17, não detectamos níveis significativos desta citocina em sobrenadante de cultura de células do LBA em nenhum dos grupos estudados, sendo que o limite de detecção para a IL-17 foi 15.6 $\mathrm{pg} / \mathrm{ml}$ a $1000 \mathrm{pg} / \mathrm{ml}$.

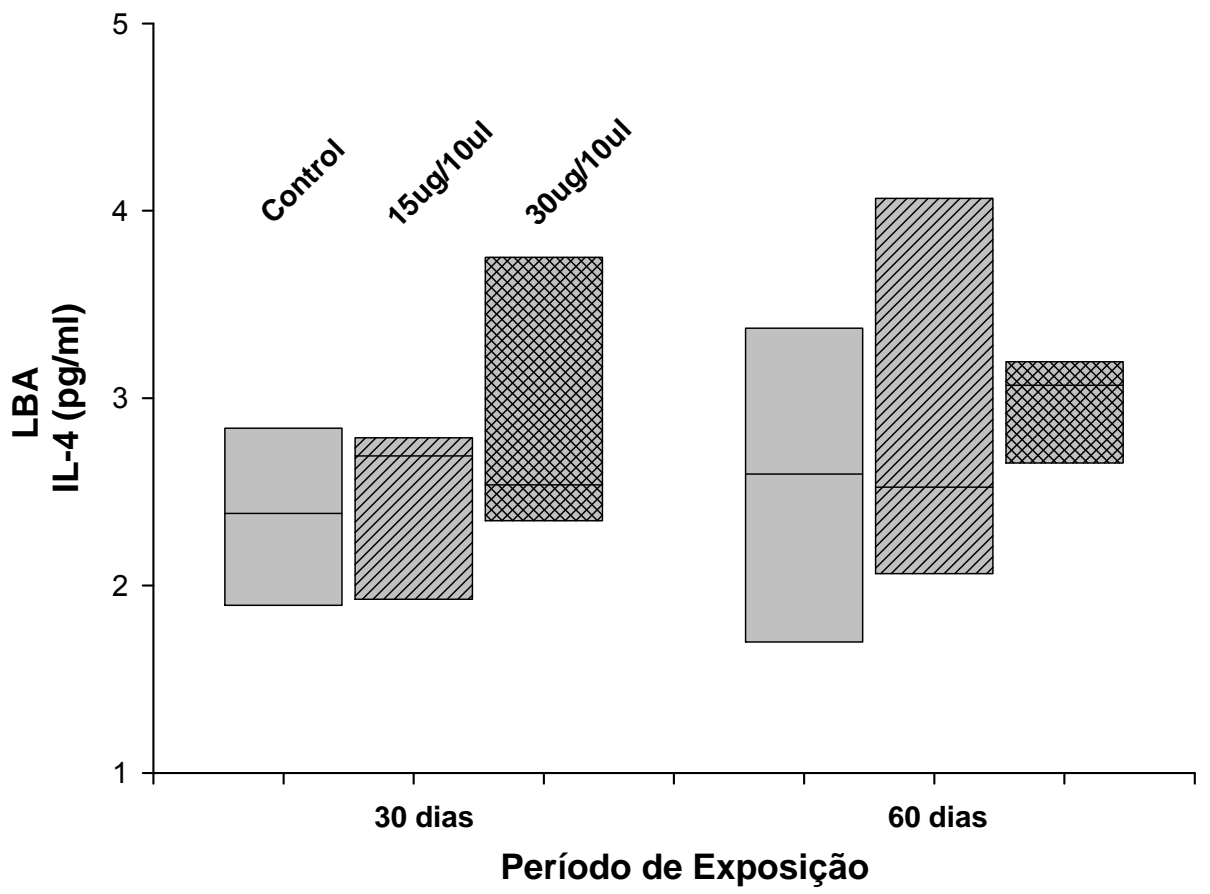

Gráfico 10: Efeito do DEP de concentrações $15 \mu \mathrm{g} / 10 \mu \mathrm{l}$ e $30 \mu \mathrm{g} / 10 \mu \mathrm{l}$ de salina e grupo Controle sobre células inflamatórias positivas para IL- 4 . Valores expressos em box plot (detalhes descritos no gráfico 1). Não houve diferença estatística quando instilado $15 \mu \mathrm{g} / 10 \mu \mathrm{l}$ e $30 \mu \mathrm{g} / 10 \mu \mathrm{l}$ de solução salina, após 30 e 60 dias. 


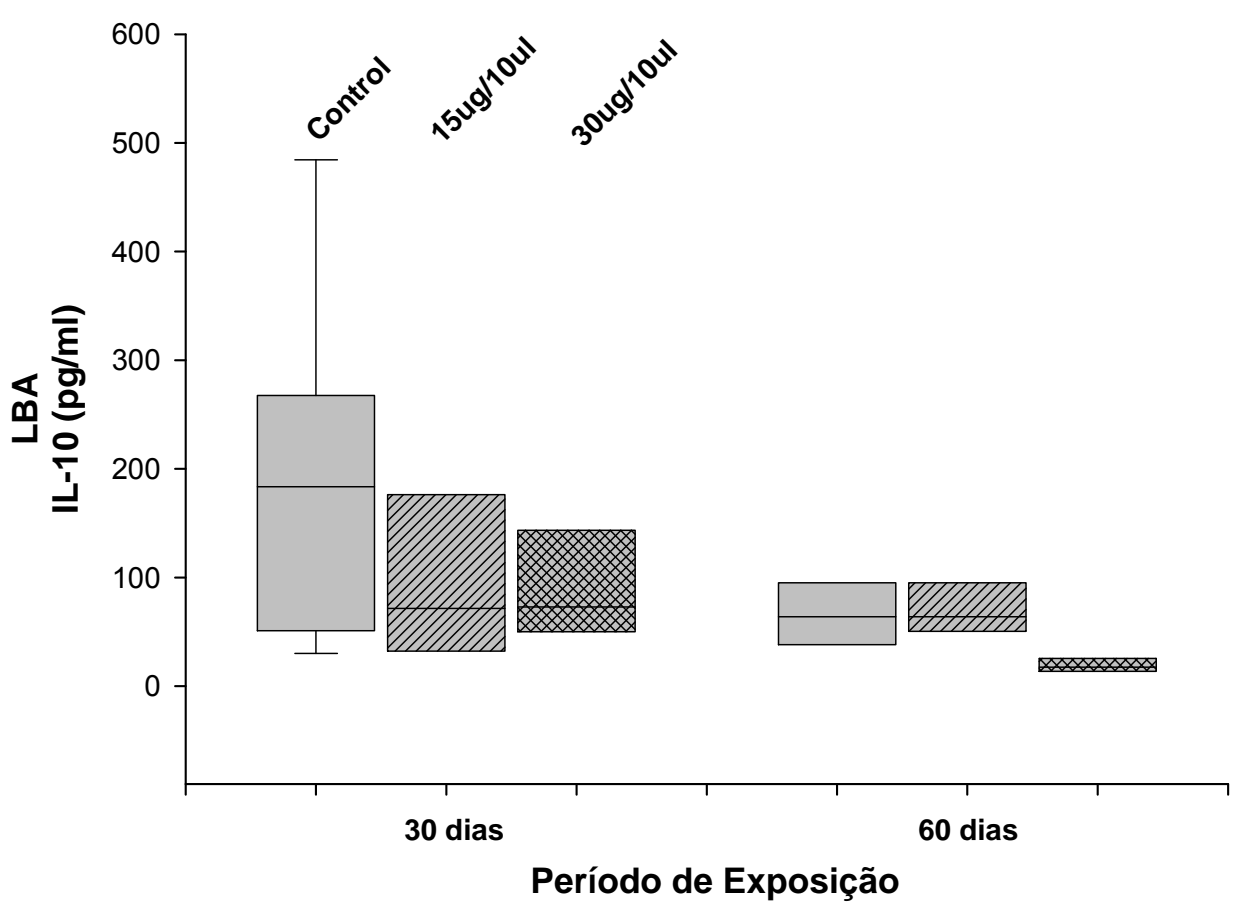

Gráfico 11: Efeito do DEP de concentrações $15 \mu \mathrm{g} / 10 \mu \mathrm{l}$ e $30 \mu \mathrm{g} / 10 \mu \mathrm{l}$ de salina e grupo Controle sobre células inflamatórias positivas para IL- 10 . Valores expressos em box plot (detalhes descritos no gráfico 1). O grupo de animais que receberam instilação de $15 \mu \mathrm{g} / 10 \mu \mathrm{l}$ de salina e $30 \mu \mathrm{g} / 10 \mu \mathrm{l}$ de solução salina, após 30 e 60 dias não houve diferença quando comparado com o grupo Controle. 
Na figura 9 observa-se um exemplo do epitélio respiratório que reveste o trato respiratório distal (brônquio e bronquíolos) nos animais dos grupos Controle e expostos ao DEP de concentrações $15 \mu \mathrm{g} / 10 \mu \mathrm{l}$ de salina e $30 \mu \mathrm{g} / 10 \mu \mathrm{l}$ de salina, no período de exposição 30 e 60 dias.

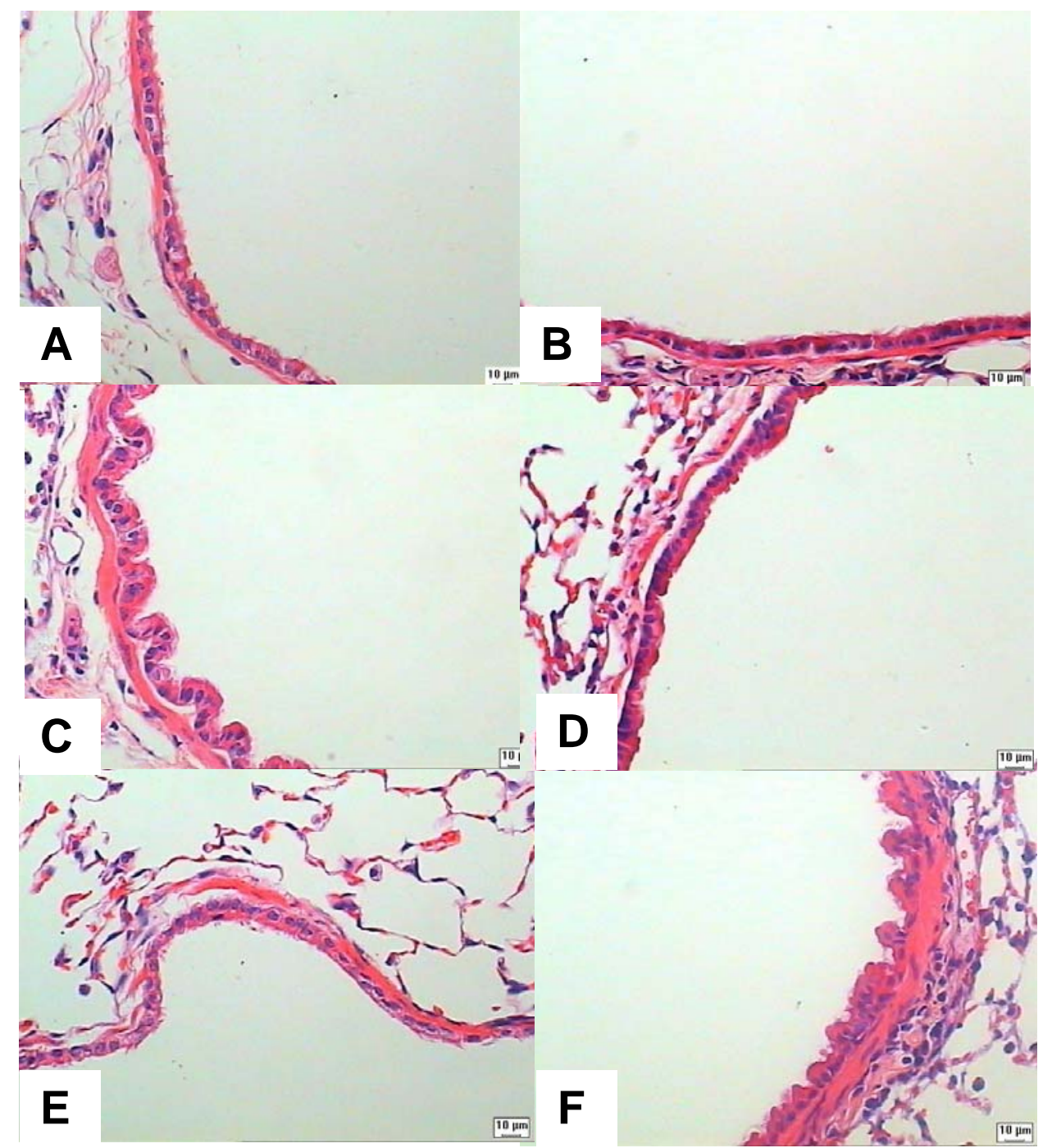

Figura 9: Representação histológica do epitélio brônquico no grupo Controle após 30 dias de instilação de solução salina (A), grupo Controle 60 dias (B); e grupo exposto ao DEP de concentrações $15 \mu \mathrm{g} / 10 \mu \mathrm{l}$ de salina após 30

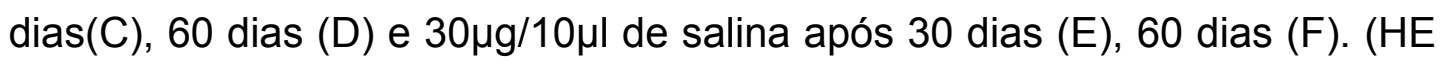
400x). 
O gráfico 12 apresenta os resultados da analise da espessura de epitélio do trato respiratório distal para todos os grupos e tempos de exposição de 30 e 60 dias de exposição. A exposição ao DEP induz a um aumento da espessura do trato respiratório distal, após 30 dias na concentração de DEP $15 \mu \mathrm{g} / 10 \mu \mathrm{l}$ de solução salina quando comparado com o grupo DEP $30 \mu \mathrm{g} / 10 \mu \mathrm{l}$ de solução salina $(p=0,024)$. Após 60 dias de exposição não houve diferença significante entre os grupos.

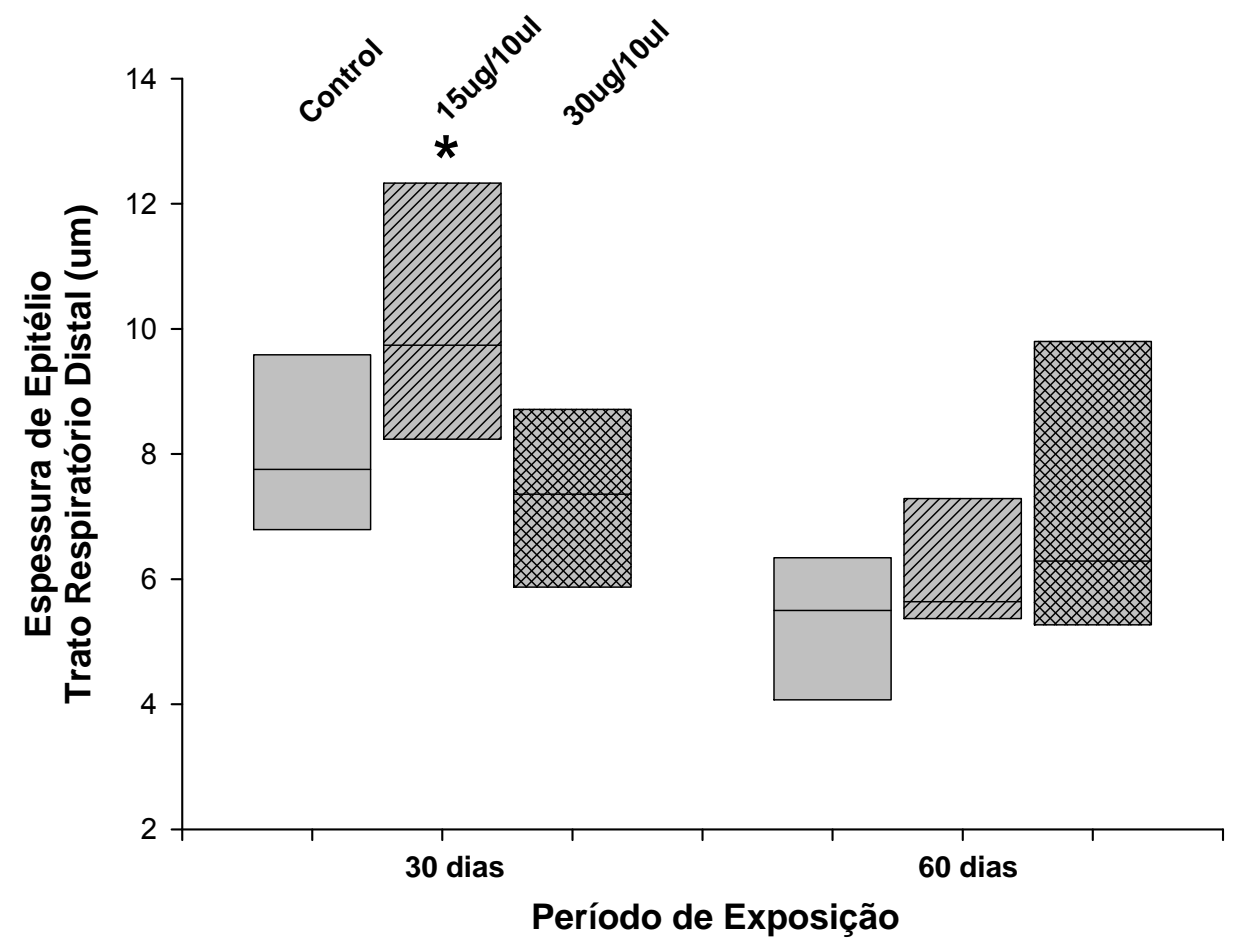

Gráfico 12: Efeitos do DEP sobre a espessura da camada epitelial do trato respiratório distal. Grupo Controle e grupo exposto ao DEP nas concentrações de $15 \mu \mathrm{g} / 10 \mu \mathrm{l}$ e $30 \mu \mathrm{g} / 10 \mu \mathrm{l}$ de solução salina, nos períodos de exposição de 30 e 60 dias. Valores expressos em box plot (detalhes descritos no gráfico 1). $O$ grupo dos animais expostos a $15 \mu \mathrm{g} / 10 \mu \mathrm{l}$ de salina após 30 dias de exposição mostrou uma diferença estatisticamente significante em relação ao grupo DEP $30 \mu \mathrm{g} / 10 \mu \mathrm{l}$ de salina. * $p=0,024$ 
A expressão do gene MUC5ac foi avaliada através da quantificação de proteínas no tecido pulmonar. O gráfico abaixo representa a expressão reativa do gene MUC5ac dos animais que receberam o DEP nas concentrações de $15 \mu \mathrm{g} / 10 \mu \mathrm{l}$ de salina, $30 \mu \mathrm{g} / 10 \mu \mathrm{l}$ de salina e grupo Controle no período de 30 e 60 dias. Os animais que receberam DEP $30 \mu \mathrm{g} / 10 \mu \mathrm{l}$ de salina após 60 dias mostrou um aumento da expressão do gene MUC5ac no tecido pulmonar quando comparado com os grupos Controle e DEP $15 \mu \mathrm{g} / 10 \mu \mathrm{l}$ de solução salina $(p=<0,016)$.

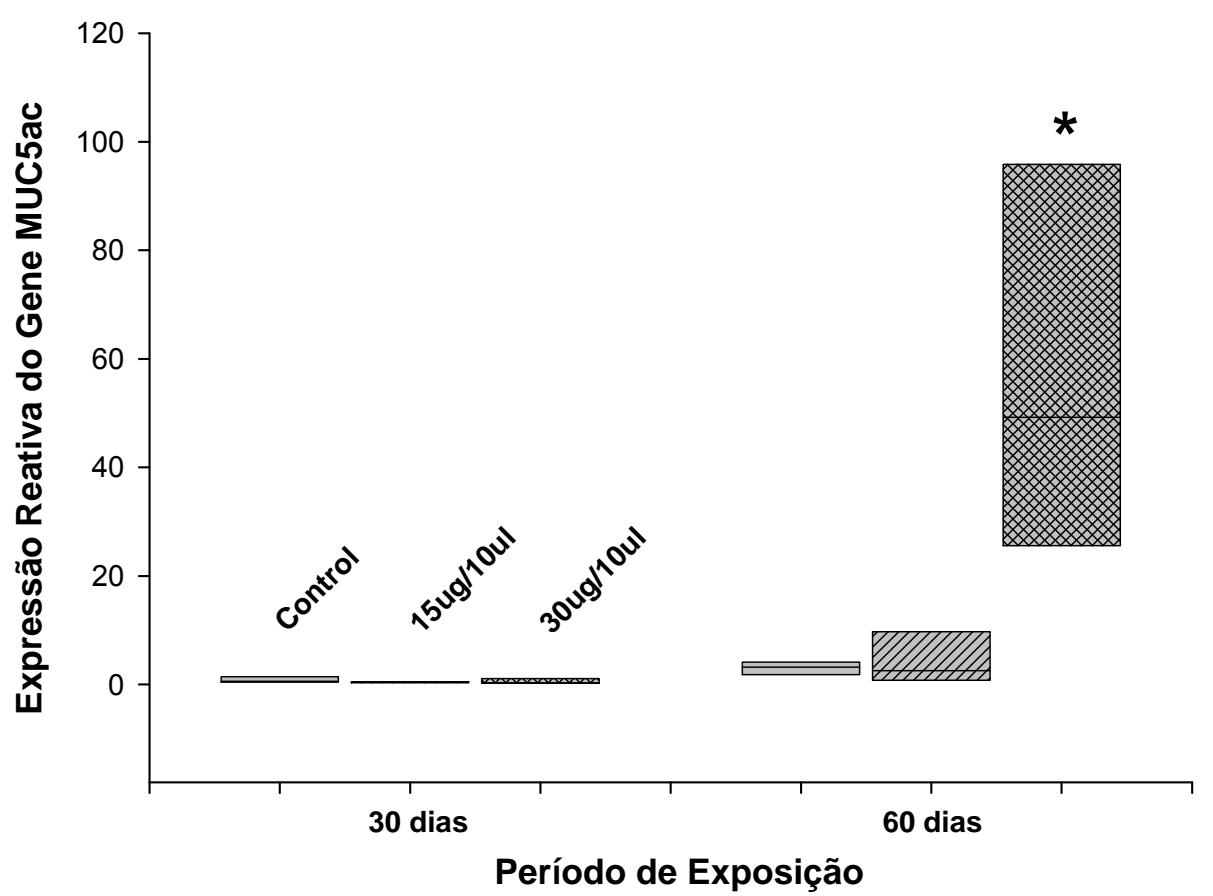

Gráfico 13: Efeito do DEP de concentrações de DEP $15 \mu \mathrm{g} / 10 \mu \mathrm{l}$ e $30 \mu \mathrm{g} / 10 \mu \mathrm{l}$ de salina e grupo Controle sobre a expressão reativa do gene de MUC5ac de tecido pulmonar. Valores expressos em box plot (detalhes descritos no gráfico 1). Os animais que receberam DEP $30 \mu \mathrm{g} / 10 \mu \mathrm{l}$ de salina, após 60 dias, mostrou diferença significativa da expressão do gene MUC5ac no 
tecido pulmonar quando comparado com os grupos Controle e DEP $15 \mu \mathrm{g} / 10 \mu \mathrm{l}$ de solução salina * $p=<0,016$.

Os painéis de fotomicrografias representam, respectivamente, a expressão de inflamação peribrônquica positiva para IL-13.

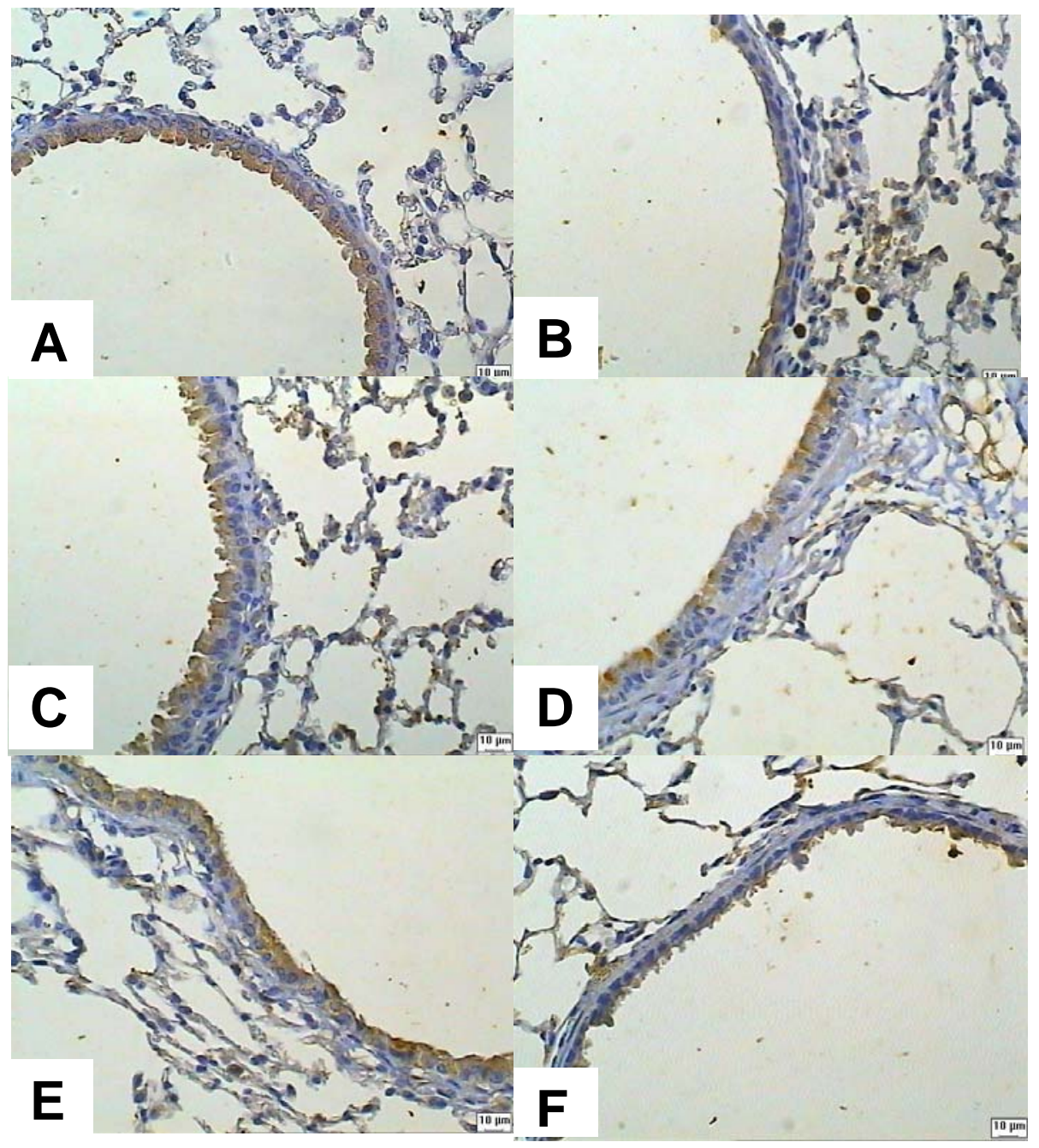

Figura 10: Representação histológica da expressão de IL-13 do epitélio peribrônquico no grupo Controle 30 dias (A), grupo Controle 60 dias (B); e grupo exposto ao DEP de concentrações $15 \mu \mathrm{g} / 10 \mu \mathrm{l}$ de salina após 30 dias

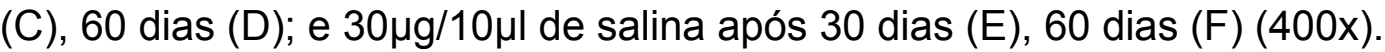


A figura abaixo representa a relação de área de inflamação peribrônquica positiva para IL-13 sobre a área do epitélio brônquico. A exposição ao DEP não alterou a expressão de células inflamatórias positivas para IL-13 no epitélio brônquico quando comparado entre os grupos após 30 e 60 dias.

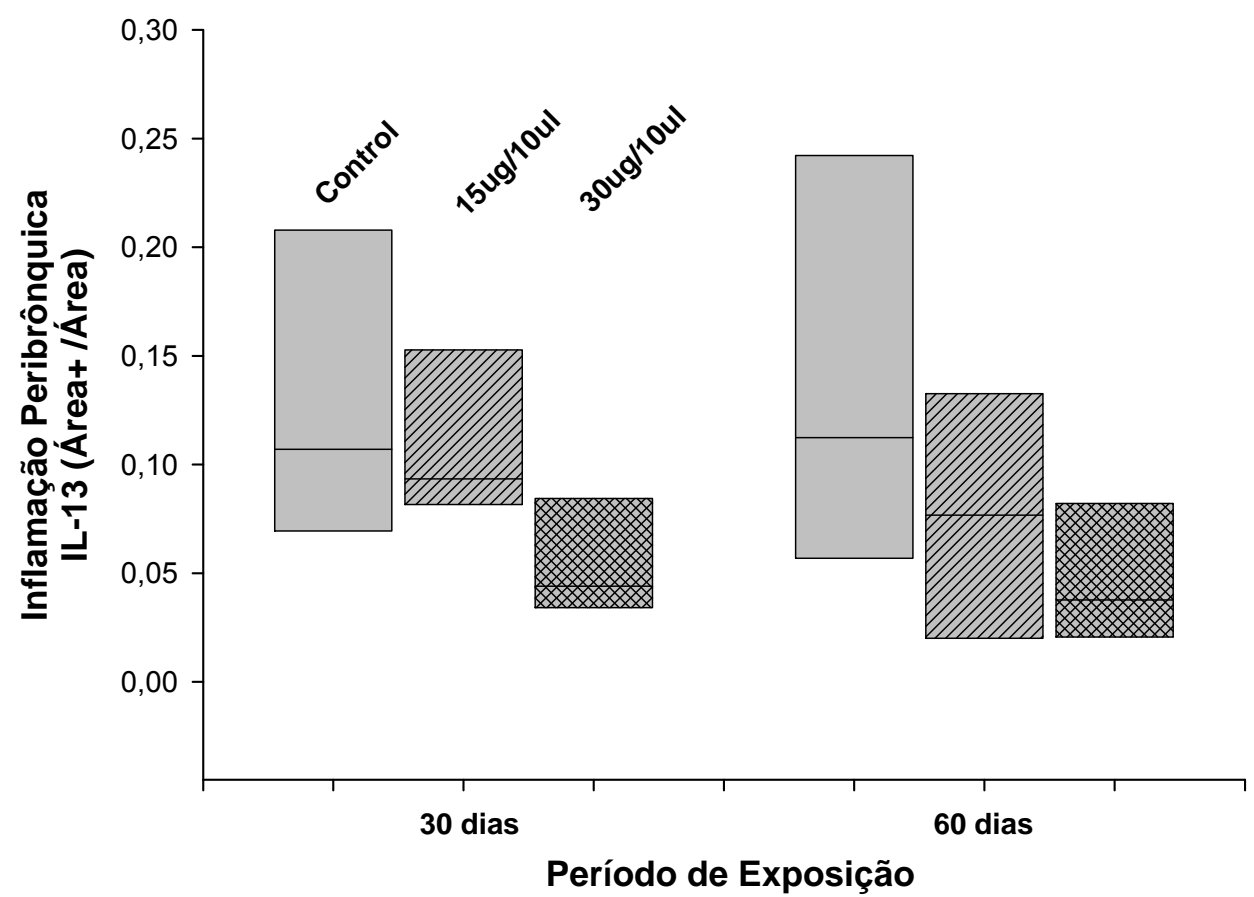

Gráfico 14: Efeitos do DEP nas concentrações de concentrações $15 \mu \mathrm{g} / 10 \mu \mathrm{l}$ e $30 \mu g / 10 \mu l$ de salina e grupo Controle sobre a expressão de inflamação peribrônquica positiva para IL-13. Valores expressos em box plot (detalhes descritos no gráfico 1). Não houve diferença estatística quando instilado $15 \mu \mathrm{g} / 10 \mu \mathrm{l}$ e $30 \mu \mathrm{g} / 10 \mu \mathrm{l}$ de solução salina, após 30 e 60 dias.

A figura abaixo representa a relação de área de inflamação peribrônquica positiva para IL-13 sobre a membrana basal. A exposição ao 
DEP não alterou a expressão de células inflamatórias positivas para IL-13 no epitélio brônquico quando comparado entre os grupos após 30 e 60 dias.

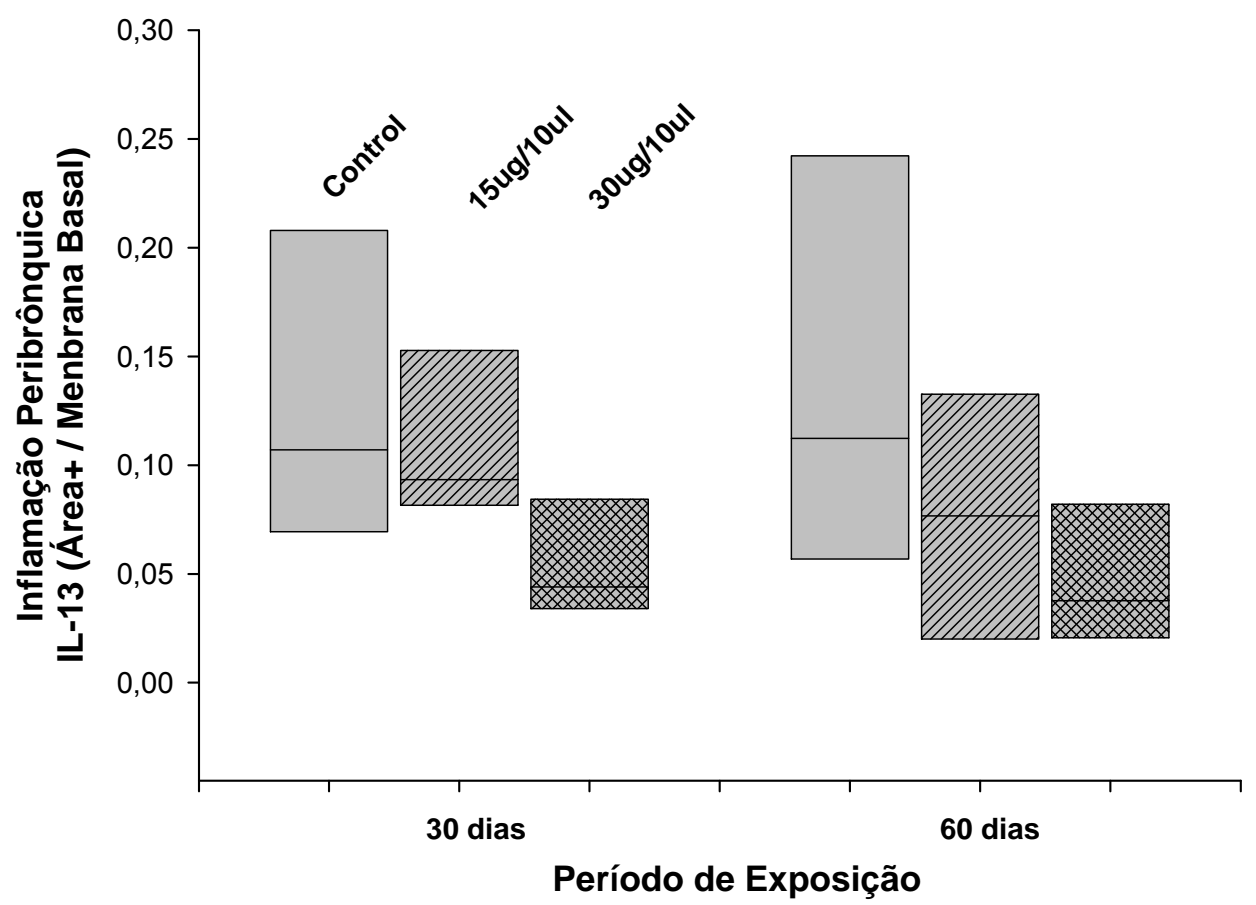

Figura 15: Efeitos do DEP nas concentrações de concentrações 15 $\mu \mathrm{g} / 10 \mu \mathrm{l}$ e $30 \mu g / 10 \mu l$ de salina e grupo Controle sobre a expressão de inflamação peribrônquica positiva para IL-13. Valores expressos em box plot (detalhes descritos no gráfico 1). Não houve diferença estatística quando instilado $15 \mu \mathrm{g} / 10 \mu \mathrm{l}$ e $30 \mu \mathrm{g} / 10 \mu \mathrm{l}$ de solução salina, após 30 e 60 dias. 
$\mathrm{Na}$ área alveolar dos pulmões, macrófagos contendo pontos negros de pigmentos de carbono no citoplasma (Figura 11) foram observados nos grupos instilados com DEP 30 após 60 dias.

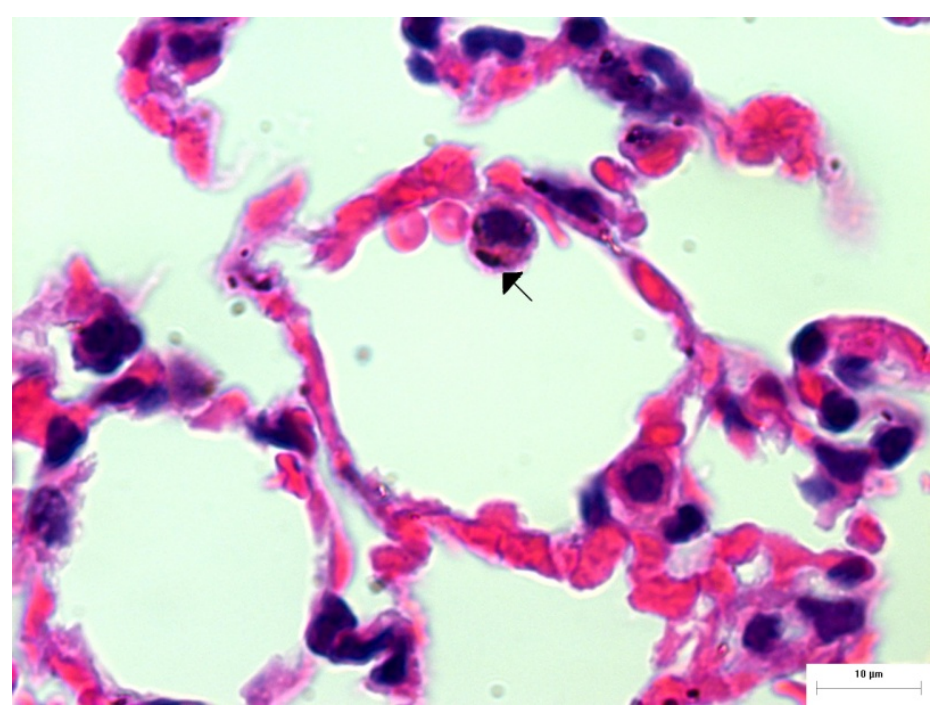

Figura 11: Partículas de Diesel fagocitadas pelo macrófago no pulmão após 60 dias no grupo que recebeu DEP30. Pontos negros de pigmentos de carbono foram observados em Fotomicrografia (1380X). (HE). 


\section{DISCUSSÃO}

Diversos trabalhos têm analisado os efeitos das partículas de diesel no epitélio respiratório (vias aéreas superiores e ou inferiores) em animais previamente sensibilizados com ovalbumina (OVA), proteína que desencadeia uma resposta inflamatória. Quando estes animais são expostos ao diesel, a gravidade e a prevalência de doenças alérgicas aumentam (Takano et al. 1997, Inoue et al. 2007, Hashimoto et al., 2001). Sydbom et al, (2001), entretanto, alertam para o fato de que as experiências nesse sentido têm relatado alta doses de diesel administradas em animais saudáveis, muito maior que aquelas presentes em pessoas expostas a ele na vida diária.

A compreensão dos mecanismos pelo qual a exposição à poluição do ar afeta a saúde humana e de qual constituinte desta complexa mistura é responsável pelos efeitos é importante para proteger a população por meio de intervenções ou regulações. Embora experimentos com animais tenham sido valiosos na determinação de possíveis caminhos, a inferência (extrapolação) de roedores ou outros animais de experimentação é utilizada para confirmação dos efeitos no sistema humano (Seagrave et al, 2007). A instilação intranasal de DEP é uma técnica não invasiva para o animal, de fácil aplicabilidade, e administrável em pequenas quantidades.

Os resultados deste trabalho sugerem que a exposição subcrônica de material particulado do diesel administrado por via intranasal pode induzir a inflamação das vias aéreas superiores e inferiores em camundongos 
saudáveis (Gráfico 4). Os animais receberam instilação intranasal de baixas

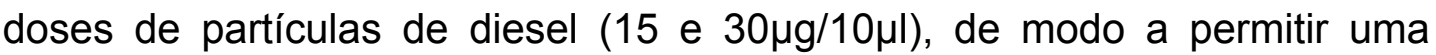
caracterização de seu impacto no trato respiratório.

A concentração média anual de $\mathrm{PM}_{10}$ na cidade de São Paulo oscila em torno de $40 \mu \mathrm{g} / \mathrm{m}^{3}$. Durante o inverno, níveis de $100 \mu \mathrm{g} / \mathrm{m}^{3}$ ou acima foram frequentemente observados. Medições de campo realizadas por nossa equipe em um corredor de ônibus da cidade de São Paulo mostraram níveis de $150 \mu \mathrm{g} / \mathrm{m}^{3}$ das $6 \mathrm{~h}$ da manhã às $4 \mathrm{~h}$ da tarde.

Considerando-se que numa ventilação diária do camundongo o volume corrente é em torno de $0,17 \mathrm{~m}^{3} \cong 1 \mathrm{~m}^{3}$ e a frequência respiratória é de 120 rpm (respirações por minuto), $30 \mu \mathrm{g}$ de DEP corresponderia aproximadamente à dose acumulada recebida por um camundongo, equivalente ao cenário de um corredor de ônibus urbano em nossa cidade.

As alterações estruturais mais evidentes observadas neste trabalho foram no epitélio nasal (Figura 8; Gráfico 1). Esse achado pode ter sido devido ao protocolo de administração - a instilação nasal -, que pode ter contribuído para uma maior dose de proporcionalidade para esse segmento do trato respiratório. No entanto, a histologia descritiva realizada nos bronquíolos também observou danos aos pulmões e expressão do gene MUC5ac no pulmão dos animais expostos ao DEP (Gráfico 13) .

Essas alterações significativas evidenciadas por baixas doses de DEP podem ter resultado do tipo de combustível e tecnologia de motor à diesel disponível na cidade de São Paulo e outras cidades dos países em desenvolvimento. 
Isso se dá porque o diesel atualmente distribuído nas principais capitais do Brasil -S500- tem 500 partes por milhão (ppm) de enxofre em sua composição. No entanto, o chamado diesel interior - S1800- utilizados em outras cidades brasileiras, contém 1.800 ppm de enxofre do combustível, mas ambos podem causar problemas cardíacos e respiratórios em humanos (CETESB, 2008).

O teor de enxofre dos combustíveis de petróleo contribui para a formação de dióxido de enxofre $\left(\mathrm{SO}_{2}\right)$, que causa tanto a deposição ácida como a intoxicação dos conversores catalíticos nos veículos. O aumento de enxofre no combustível resulta em aumento das emissões nas partículas do diesel (Liang et al., 2006). Uma grande fração de enxofre orgânico nos combustíveis a diesel ocorre em estruturas aromáticas, como, por exemplo, em homólogos alquilados de heteropolicíclicos aromáticos (HPA) de enxofre, que são possíveis causadoras de lesões pulmonares (Liang et al., 2006). Devido ao alto teor de enxofre não há catalisadores nos motores de veículos pesados da frota brasileira.

Este trabalho sugere que o epitélio respiratório não possui uma resposta adaptativa ao DEP, mas uma resposta tempo dependente, diferentemente da resposta ao ozônio, caso em que, após vários insultos, o organismo produz substâncias como respostas para garantir o restabelecimento de suas funções principais, tais como substâncias antioxidantes (Saldiva, et al, 2005).

$\mathrm{O} \mathrm{SO}_{2}$ inalado no epitélio da via aérea facilmente forma os derivados solúveis in vivo (bissulfito e sulfito), que são tóxicos para o sistema 
respiratório e relacionados com a exacerbação da asma. Estudos realizados por Li e Meng (2007) demonstraram que a exposição ao $\mathrm{SO}_{2}$ de cultura de células epiteliais brônquicas humanas levou a um aumento da expressão do RNAm de MUC5AC e IL-13, sugerindo que os derivados de $\mathrm{SO}_{2}$ podem induzir a uma produção excessiva de muco e respostas inflamatórias em células epiteliais brônquicas de origem humana, além de poderem estar relacionados à doença asmática.

Os resultados deste trabalho mostram que após 60 dias a exposição de camundongos a diesel causou um acréscimo de muco ácido no septo nasal, e aumento de MUC5AC nos pulmões. Não foi observado, entretanto, um aumento de IL-13 (Gráfico 9), um importante mediador da inflamação alérgica que confere um maior risco de doenças respiratórias atópicas como a asma, o que sugere que a hipersecreção de muco pode estar associada à qualidade do DEP utilizados, levando a uma possível inflamação em camundongos saudáveis.

Cohn et al. (1994), estabeleceram o papel de células Th2 na produção de muco, demonstrando que IL-4 é crucial para recrutar células Th2 para o pulmão e para indução da inflamação, mas não está diretamente ligada com a produção de muco. Em nosso estudo, o nível de IL-4 e IL-10 não alterou nos grupos expostos ao diesel que receberam concentrações variadas em dois períodos de tempo (Gráfico 10 e 11) .

Além disso, parte do material particulado que é instilado é perdida através de deglutição e dos mecanismos de defesa pulmonar. Em nosso estudo, o tamanho das partículas apresentou grande variação entre as 
partículas com diâmetro inferior a $2.5 \mu \mathrm{m}$, que representam os $30 \%$ que atingiram os alvéolos e lá foram depositadas.

Muitas das partículas que entram em contato com o epitélio respiratório são eliminadas pelo mecanismo de depuração (clearance) mucociliar e conduzidas até a via aérea, assim como pelos macrófagos que fagocitam essas partículas. Squiban et al (1999) comentam que, após exposição crônica o mecanismo de depuração mucociliar pode ser prejudicado, levando a uma permanência maior das partículas na via aérea. Nesse caso, essas partículas que entram em contato com o epitélio da via aérea podem induzir dano celular. Neste estudo, observamos que a partículas de diesel foram fagocitadas pelo macrófago no pulmão do grupo DEP30 após 60 dias de instilação intranasal (Figura 11), o que indica que as partículas de diesel foram depositadas no parênquima pulmonar.

Evidências de alteração no mesmo padrão temporal foram observadas nas contagens das células totais do LBA nos pulmões dos animais pesquisados. Nesse estudo observou-se hiperplasia das células caliciformes no epitélio nasal (Gráfico 2). A literatura relata que a hiperplasia ocorre principalmente devido à maior concentração de interleucinas, mas este trabalho de pesquisa não avaliou o nível de interleucina nasal.

Roger (2003) aponta para o fato de que, entre os inúmeros estímulos para a hiperplasia de células caliciformes, os linfócitos auxiliares (T helper-2 ou Th2) derivados de citocinas IL-4, IL-9 e IL-13 são altamente eficazes na indução da síntese de mucina e / ou taxa hiperplasia de células em sistemas experimentais. Portanto, como a porta de entrada para o sistema respiratório 
é o nariz, este deve ser o primeiro a responder aos insultos causados pelo DEP. 
CONCLUSÕES 


\section{CONCLUSÕES}

Este trabalho conclui que baixas doses e exposição subcrônica à combustão de diesel induz à inflamação no septo nasal e bronquíolos de camundongos saudáveis. Estes resultados sugerem que a exposição a DEPs é capaz de promover significativamente lesão pulmonar, que aumenta com o tempo. Os resultados obtidos no presente trabalho nos permitiram concluir que:

1) baixas doses de partículas de diesel levam a alterações no trato respiratório.

2) O DEP levou ao aumento da espessura do epitélio nasal e alterou a propriedade física do muco, e que estas alterações foram tempo dependente.

3) As partículas de diesel foram depositadas no parênquima pulmonar, que pode ser observada pelos macrófagos fagocitando as partículas de diesel.

O padrão anual de poluentes preserva a saúde pública, e estudos utilizando baixas doses e longos períodos de exposição permitem uma melhor caracterização dos níveis encontrados na vida real. Nossos resultados mostram a necessidade de incentivar a adoção de combustíveis mais limpos e tecnologia de motores a diesel mais avançada em países em desenvolvimento. 
REFERÊNCIAS BIBLIOGRÁFICAS 


\section{REFERÊNCIAS BILIOGRÁFICAS}

Awaya H, Takeshima Y, Yamasaki M, Inai K. Expression of MUC1, MUC2, MUC5AC, and MUC6 in atypical adenomatous hyperplasia, bronchioloalveolar carcinoma, adenocarcinoma with mixed subtypes, and mucinous bronchioloalveolar carcinoma of the lung. Am J Clin Pathol. 2004 May;121(5):644-53.

Abbas, AK., Lichtman, AH, Pober JS. Propriedades gerais das respostas imunes. In: Imunologia celular e molecular. Cap 1, Ed. Revinter, 2003. 544p.

Becker S, Soukup JM, Gilmour MI, Devlin RB. Stimulation of human and rat alveolar macrophages by urban air particulates: effects on oxidant radical generation and cytokine production. Toxicol Appl Pharmacol 1996; 141: 637648.

Boland S, Baeza-Squiban A, Fournier T, Houcine O, Gendron MC, Chevrier M, Jouvenot G, Coste A, Aubier M, Marano F. Diesel exhaust particles are taken up by human airway epithelial cells in vitro and alter cytokine production. Am J Physiol Lung Cell Mol Physiol. 1999; 276(4):L604-L613.

Brain JD, Valberg PA. Deposition of aerosol in the respiratory tract. Am Rev Pespir Dis. 1979; 120: 1325-1373. 
Brook RD. Cardiovascular effects of air pollution. Clinical Science. 2008; 115: $175-187$

CETESB (Companhia de Tecnologia de Saneamento Ambiental). Relatório de qualidade do ar do estado de São Paulo 2008. Série Relatório Secretaria do Estado do Meio Ambiente. São Paulo: CETESB; 2008. Disponível em: URL:http//:www.cetesb.sp.gov.br/AR.

Cohn L, Homer RJ, Marinov A, Rankin J, Bottomly K. Induction of Airway Mucus Production By T Helper 2 (Th2) Cells: A Critical Role For Interleukin 4 In Cell Recruitment But Not Mucus Production. J. Exp. Med. 1997; 186: (10)1737-1747.

Clarke RW, Catalano PJ, Koutrakis P, Krishna Murthy CG, Sioutas C, Paulaskis J, Coull B, Ferguson S, Godleski JJ. Urban air particulate inhalation alters pulmonary function and induces pulmonary inflammation in a rodent model of chronic bronchitis. Inhal Toxicol 1999; 11:637-656.

de Oliveira AP, Domingos HV, Cavriani, G., Damazo, A.S., Dos Santos Franco, A.L., Oliani, S.M., Oliveira-Filho, R.M., Vargaftig, B.B., de Lima, W.T. Cellular recruitment and cytokine generation in a rat model of allergic lung 
inflammation are differentially modulated by progesterone and estradiol. Am. J. Physiol. Cell. Physiol. 2007; 293(3): C1120-1128.

Devouassoux G, Brambilla C. Effect of diesel particles on allergic inflammatory response: cellular targets and molecular mechanisms. Rev. Mal. Respir. Sep 2002; 19 (4): 467-479. Review. French

Diaz-Sanchez, D., Tsien, A., Casillas, A., Dotson, A., and Saxon, A. Enhanced nasal cytokine production in human beings after in vivo challenge with diesel exhaust particles. J. Allergy Clin. Immunol. 1996. 98:114-123.

Dockery DW, Pope III CA, Xu X, Spengler JD, Ware JH, Fay ME, Ferris Jr BG, Speizer FE. An association between air pollution and mortality in six US: cities. N. Eng.l J. Med. 1993; 329: 1753-1759.

Hashimoto KI, Ishii $\mathrm{Y}$, Uchida $\mathrm{Y}$, Kimura T, Masuyama K, Morishima $\mathrm{Y}$, Hirano K, Nomura A, Sakamoto T, Takano H, Sagai M, Sekizawa K. Exposure to diesel exhaust exacerbates allergen-induce airway responses in guinea pigs. Am J Respir Crit Care Med. 2001; 164: 1957-1963.

Herbert RA, Leininger JR. Nose, larynx and trachea. In: Maronpot, R.R. (Ed.), Pathology of the Mouse: Reference and Atlas. 1999.pp. 259-292. 
Hovenberg, HW, Davies JR, Carlstedt I. Different mucins are produced by the surface epitelium and the submucosa in human trachea: identification of MUC5AC as a major mucin from goblet cells. Biochem J 1996; 318: 319-324.

Inoue KI, Takano T, Ichinose T, Tomura S, Yanagisawa R, Sakurai M, Sumi D, Cho AK, Hiyoshi K, Kumagai Y. Effects of naphthoquinone on airway responsiveness in the presence or absence of antigen in mice. Arch Toxicol. $2007 ; 81: 575-581$

Jiang C, Finkbeiner WE, Winddicombe JH, McCray PB Jr, Miller SS. Science. 1993; 262(5132):424-7.

Junqueira LC \& CarneiroJ. A célula. Em: Junqueira LC, Carneiro J. Histologia Básica. Rio de Janeiro: Editora Guanabara Koogan; 1985. p.2957.

Kampa M, Castanas E. Human health effects of air pollution. Environ. Pollut.xx. 2007;1-6.

Kanemitsu H, Nagasawa S, Sagai M, Mori Y. Complement activation by diesel exhaust particles (DEP). Biol. Pharm. Bull. 1998; 21: 129-132.

Knowles MR \& Boucher RC. Mucus clearance as a primary innate defense mechanism for mammalian airways. J Clin Invest. 2002; 109(5): 571-7. 
Konietzko N. Muçus transport and inflammation. Eur J Respir Dis Suppl. $1986 ; 147: 72-9$.

Laks D, Oliveira R C, André P A, Macchione M, Lemos M, Faffe D, Saldiva PHN, Zin W A. Composition of Diesel Particles Influences Acute Pulmonary Toxicity: Na Experimental Study in MICE. Inhal. Toxicol, 2008; 20(11): 10371042.

Li N, Hao M, Phalen RF, Hinds WC, Nel AE. Particulate air pollutants and asthma. A paradigm for the role of oxidative stress in PM-induced adverse health effects. Clin. Immunol. 2003; 109: 250-265.

Li R \& Meng Z. Effects of SO2 derivatives on expressions of MUC5AC and IL-13 in human bronchial epithelial cells. Arch Toxicol 2007; 81:867-874.

Liang F, Lu M, Birch EB, Keener TC, Liu Z. Determination of polycyclic aromatic sulfur heterocycles in diesel particulate matter and diesel fuel by gas chromatography with atomic emission detection. Journal of Chromatography A. 2006;1114: 145-153.

Lorenzi-Filho G, Bohm GM, Guimarães ET, Costa-Vaz MA, King M, Saldiva PHN. Correlation between rheological properties and in vitro ciliary transport of rat nasal mucus. Biorheology. 1992; 29:433-40. 
Medeiros NJr, Riveiro DH, Kasahara DI, Saiki M, Goledski J, Koutrakis P, Capelozi VL, Saldiva PH, Antonangelo L. Acute pulmonary and hematological effects of two types of particles surrogates are influenced by their elemental composition. Environ. Res. 2004; 95(1): 62-70

Pandya RJ, Solomon G, Kinner A, Balmes JR. Diesel exhaust and asthma: hypoteses and molecular mechanisms of action. Environmental Health Perspectives. 2002; 110: 103-112.

Peterson B, Saxon A. Global increases in allergic respiratory disease: the possible role of diesel exhaust particles. Ann Allergy Asthma Immunol. 1996; 77: $263-268$

Pires-Neto RC, Lichtenfels AJ, Soares SR, Macchione M, Saldiva PH N, Dolhnikoff M. Effects of São Paulo air pollution on the upper airways of mice. Environ. Res. 2006; 101(3): 356-361.

Pope III CA, Burnett RT, Thurston GD, Thun MJ, Calle EE, Krewski D, Godleski JJ. Cardiovascular Mortality and Long-Term Exposure to Particulate Air Pollution: Epidemiological Evidence of General Pathophysiological Pathways of Disease. Circulation. 2004; 109: 71-77.

Pourazar J, Frew AJ, Blomberg A, Helleday R, Kelly FJ, Wilson S, Sandstrom T. Diesel exhaust exposure enhances the expression of IL-13 in 
the bronchial epithelium of healthy subjects. Respir. Med. 2004; 98(9): 821825.

Rose MC \& Voynon JA. Respiratory tract mucin genes and mucin glycoproteins in health and diseases. Physiol Rev. 2006; 86:245-278.

Rogers DF. The airway goblet cell. The International Journal of Biochemistry \& Cell Biology. 2003; 35: 1-6.

Reid CJ, Gould S, Harris A. Developmental expression of mucin genes in the human respiratory tract. Am J Respir Cell Mol Biol 1997;17: 592-598.

Sakakibara M, Minami M, Endo T, Hirafuji M, Murakami S, Mori Y, Sagai M. Biological effects of diesel exhaust particles (DEP) on isolated cardiac muscle of guinea pigs. Res. Comm. Mol. Pathol. Pharmacol. 1994; 86: 99110.

Saldiva PH, Künzli N, Lippmann M. Ozone. In: WHO Regional Office for Europe: Air Quality Guidelines. 2005; 11: 307-326.

Salvi S, Blomber A, Rudell B, Kelly F, Sandtrom T, Holgate ST, Frew A. Acute inflammatory responses in the airway and peripheral blood after shortterm exposure to diesel exhaust in healthy human volunteers. Am. J. Respir. Crit. Care Med. 1999; 159: 702-709. 
Samet JM. The perspective of the National Research Council's Committee on Research Priorities for Airborne Particulate Matter. J Toxicol Environ Health A. 2005;68(13-14):1063-7.

Schwartz J. What are the people dying of on high air pollution days? Environ. Res. 1994; 64: 26-35.

Seagrave JC, Sandy Dunaway S, McDonald JD, Mauderly JL, Hayden P, Stidley C. Responses Cell Biology and Toxicology of differentiated primary human lung epithelial cells to exposure to diesel exhaust at an air-liquid interface. Experimental Lung Research, 2007; 33:27-51.

Squiban AB, Bonvallot V, Boland S and Marano F. Airborne particles evoke an inflammatory response in human airway epithelium. Activation of transcription factors.. 1999; 15: 375-380.

Song Chuanwang, Liqiong Luo, Zhang Lei, Bo Li, Zhihui Liang, Guanghui Liu, Dong Li, Guimei Zhang, Bo Huang and Zuo-Hua Feng IL-17-Producing Alveolar Macrophages Mediate Allergic Lung Inflammation Related to Asthma. The Journal of Immunology, 2008; 181: 6117-6124.

Stefano ADi, Caramori G, Gnemmi I, Contoli M, Vicari C, Capelli A, Magno F, D'Anna SE, Zanini A, Brun P, Casolari P, Chung K F, Barnes PJ, Papi A, Adcock I and Balbi B. T helper type 17-related cytokine expression is 
encreased in the bronchial mucosa of stable chronic obstructive pulmonary disease patients. Clinical \& Experimental Immunology 2009; 157(2): 316-324.

Sydbom A, Blomberg A, Parnia S, Stenfors N, Sandstrom T, Dahlén S-E. Health effects of diesel exhaust emissions. Eur. Respir. J. 2001; 17: 733-746.

Takano H, Yoshikawa T, Ichinose T, Miyabara Y, Imaoka K, Sagai M.. Diesel Exhaust Particles Enhance Antigen-induced Airway Inflammation and Local Cytokine Expression in Mice. AM J RESPIR CRIT CARE MED. 1997; 156:36-42.

Takizawa H. Airway epithelial cells as regulator of airway inflammation. Int. J. Mol. Med. 1998; 1: 367-378.

Takizawa, H. Diesel exhaust particles and their effects on induce cytokine expression in human bronchial epithelial cells. Curr. Opin. Allergy Clin. Immunol. 2004; 4: 355-359.

U.S. EPA. National Air Pollutant Emission Trends. Offiic of Air Quality Planning and Research, 1900-1996, Appendix A. Washington, DC:U.S. Environmental Protection Agency, 1997.

van Rijt LS, Kuipers H, Vos N, Hijdra D, Hoogsteden HC, Lambrecht BN. A rapid flow cytometric method for determining the cellular composition of 
bronchoalveolar lavage fluid cells in mouse models of asthma. J Immunol Methods 2004; 288:111-121.

Wickstrom C, Davies JR, Eriksen GV Veerman ECI, Carlstedt I. MUC5B is a major gel-forming, oligomeric mucin from human salivary gland respiratory tract and ebdocervix: identification of glycoforms and C-terminal eleavage. Biochem J. 1998; 334: 685-693.

Willians O, Sharafkhaneh A, Kim V, Dickey BF, and Evans CM. Airway mucus: from production to secretion. Am J Respir Cell Mol Biol . 2006; 34: $527-536$.

Zanchi AC, Venturini AD, Saiki M, Saldiva PHN, Barros HMT, Rhoden CR. Chronical nasal instillation of residual-oil fly ash (ROFA) induce brain lipid peroxidation and behavioral changes in rats. Inhalation Toxicology 2008; 20 : $795-800$. 
ANEXOS 